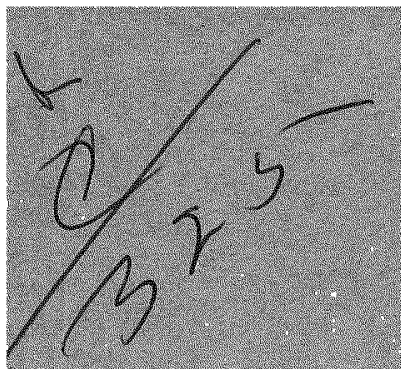

\author{
ORNL-3219 \\ UC-10-Chemical Separations Processes \\ for Plutonium and Uranium \\ TID-4500 (17th ed.)
}

\title{
AQUEOUS PROCESSING OF THORIUM FUELS
}

R. E. Blanco

L. M. Ferris

D. E. Ferguson

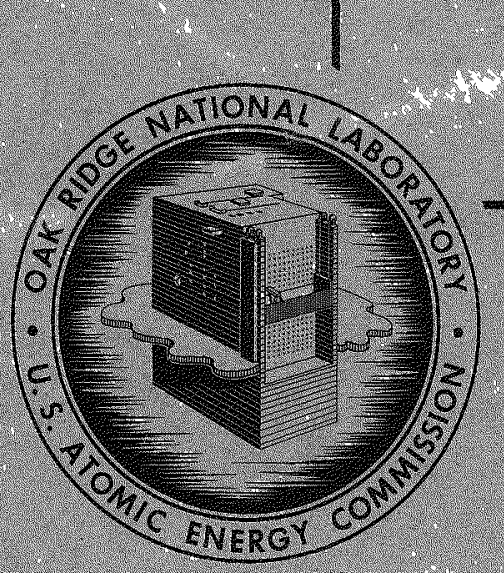

OAK RIDGE NATIONAL IABORATORY

operated by

UNION CARBIDE CORPORATION

for the

U.S. ATOMIC ENERGY COMMISSION 


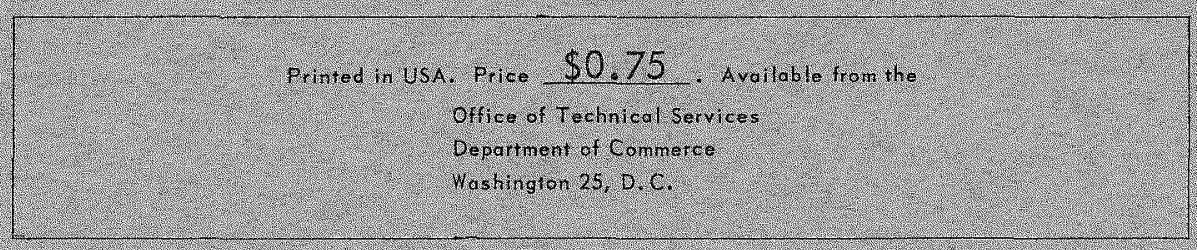

\section{LEEAL NOTICE}

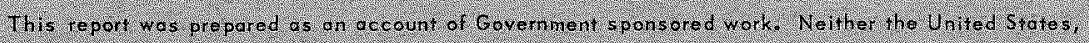

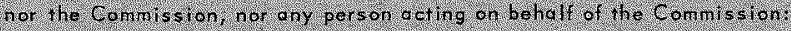

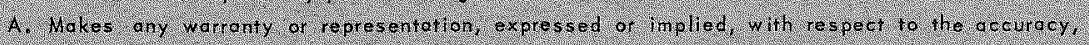

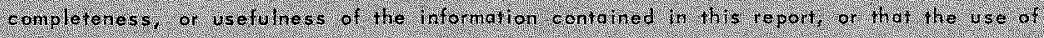

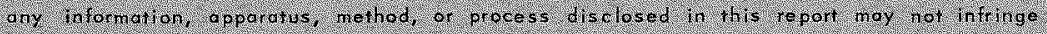

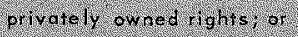

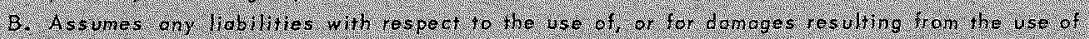

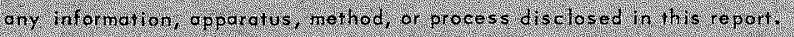

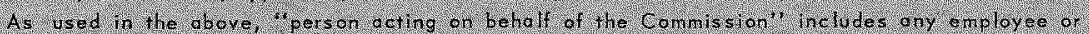

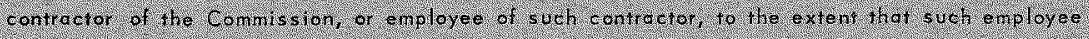

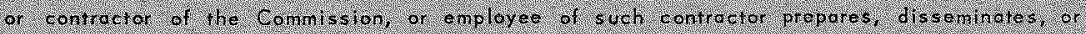

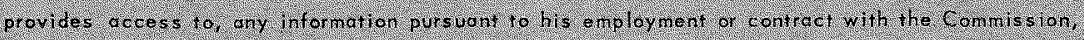
or his en ploy nert with torch contractor. 


\section{DISCLAIMER}

This report was prepared as an account of work sponsored by an agency of the United States Government. Neither the United States Government nor any agency Thereof, nor any of their employees, makes any warranty, express or implied, or assumes any legal liability or responsibility for the accuracy, completeness, or usefulness of any information, apparatus, product, or process disclosed, or represents that its use would not infringe privately owned rights. Reference herein to any specific commercial product, process, or service by trade name, trademark, manufacturer, or otherwise does not necessarily constitute or imply its endorsement, recommendation, or favoring by the United States Government or any agency thereof. The views and opinions of authors expressed herein do not necessarily state or reflect those of the United States Government or any agency thereof. 


\section{DISCLAIMER}

Portions of this document may be illegible in electronic image products. Images are produced from the best available original document. 


\author{
Contract No. W-7405-eng-26 \\ CHEMICAL TECHNOLOGY DIVISION \\ Chemical Development Sections A and B
}

AQUEOUS PROCESSING OF THORIUM FUELS

R. E. Blanco, L. M. Ferris, and D. E. Ferguson

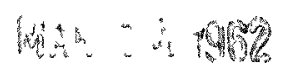

OAK RIDGE NATIONAL LABORATORY

OAK RIDGE, TENNESSEE Operated by

UNION CARBIDE CORPORATION

for the

U. S. ATOMIC ENERGY COMMISSION 


\section{ABSTRACT}

The status of aqueous processing methods for thorium fuels is summarized, with principal emphasis on the stainless steel-clad $\mathrm{ThO}_{2}-\mathrm{UO}_{2}$ type. Data were obtained principally from laboratory-scale experiments with fully irradiated fuel samples and engineering-scale tests with unirradiated fuel. Stainless steel cladding is easily dissolved with 4-6 $\mathrm{M} \mathrm{H}_{2} \mathrm{SO}_{4}$ (Sulfex process) or $5 \mathrm{M} \mathrm{HNO}_{3}-2 \mathrm{M} \mathrm{HCl}$ (Darex process) in LCNA (Nionel type) or titanium equipment, respectively, in semicontinuous or batch equipment. Uranium losses to the decladding solutions were $\sim 0.3 \%$ and $3-5 \%$ for the Sulfex and Darex processes, respectively, with fuel irradiated to $\sim 20,000$ $\mathrm{Mwd}$ /ton of core. The uranium is readily recovered from the Darex decladding solution in the acid Thorex extraction process. The $\mathrm{ThO}_{2}-\mathrm{UO}_{2}$ core is dissolved in $13 \mathrm{M} \mathrm{HNO}_{3}-0.04 \mathrm{M} \mathrm{NaF}-0.1 \mathrm{M} \mathrm{Al}\left(\mathrm{NO}_{3}\right)_{3}$.

Uranium and thorium can be recovered from graphite-base fuels by (a) disintegration and leaching with $90 \% \mathrm{HNO}_{3}$, (b) grinding and leaching with $70 \% \mathrm{HNO}_{3}$, or (c) combustion followed by dissolution in fluoride-catalyzed nitric acid.

Uranium and thorium are recovered from nitric acid solutions and separated from fission products by extraction with $30 \%$ tributyl phosphate in Amsco in the acid Thorex process. The use of an acid deficient feed $(0.15 \mathrm{M}$ a.d.) induces high decontamination while injection of nitric acid at the fourth extraction stage provides high salting strength and ensures quantitative uranium and thorium extraction. Extensive studies with other organo-phosphorous extractants established the relations between metal extraction, radiation stability, and metal complex solubility with $\mathrm{P}-\mathrm{C}$ or $\mathrm{P}-\mathrm{O}$ bonding and chain branching. Di-sec-butyl phenylphosphonate (DSBPP) combines many of the advantages found and is applicable to the separation of uranium from thorium fission products. Since the thorium distribution coefficients (or Th/F.P. separation factors) are low, none of these extractants is potentially useful for recovery and decontamination of both thorium and uranium. 


\section{CONTENTS}

Page

1.0 INTRODUCTION 4

2.0 DISSOLUTION 5

2.1 Stainless Steel Dissolution by the Sulfex Process 5

2.2 Stainless Steel Dissolution by the Darex Process 9

2.3 Aluminum Dissolution 9

$\begin{array}{ll}2.4 \text { Zirconium Dissolution } & 12\end{array}$

$\begin{array}{ll}2.5 \text { Core Dissolution } & 12\end{array}$

3.0 SOLVENT EXTRACTION 19

3.1 Feed Adjustment 19

3.2 Acid Thorex Process 21

3.3 Process Chemistry of Protactinium 25

$\begin{array}{ll}3.4 \text { New Solvents } & 26\end{array}$

$\begin{array}{ll}4.0 \text { CORROSION } & 29\end{array}$

5.0 ENGINEERING CONCEPT 29

6.0 REFERENCES $\quad 32$ 


\subsection{INTRODUCTION*}

Improved processes are being developed at Oak Ridge National Laboratory for processing irradiated thorium fuels. The primary effort has been placed on stainless steel-clad $\mathrm{ThO}_{2}-5 \% \mathrm{UO}_{2}$ as exemplified by the Consolidated Edison Indian Point Reactor fuel. Work was also initiated on graphite- and beryllia-containing fuels, with a minor effort on aluminum or Zircaloy-2-clad oxide fuels. This paper contains a summary of development work on the Darex-Thorex and Sulfex-Thorex dissolution processes (1-6), the acid Thorex solvent extraction process (7), and new extractants (8). Previously reported data (9-11) on dissolution of aluminum-clad thorium metal fuels and solvent extraction by the aluminum Thorex process are not reviewed. The latter process provides satisfactory decontamination and recoveries of thorium and uranium for fuels irradiated to about $3500 \mathrm{~g}$ of $\mathrm{U}-233$ per ton of thorium and decayed 400 days but is limited for highly irradiated fuels with short ( 30 days) decay time because of poor ruthenium decontamination, complex protactinium chemistry, solvent instability, and excessive corrosion during the evaporation-feed adjustment step. A major inherent limitation is the use of aluminum nitrate as a salting agent since the volume reduction of the waste stream is controlled by the solubility of aluminum nitrate.

Recent development work indicates a significant improvement in many of these areas, e.g., the replacement of aluminum nitrate by nitric acid, the use of sulfite reduction to increase ruthenium decontamination, the possible use of solvents with higher radiation stability and selectivity, and the use of low-temperature steam stripping to decrease corrosion during feed adjustment. The control of protactinium in separation processes remains as an outstanding problem, which is currently being studied. In addition to chemical problems, the marked tendency of protactinium to adsorb on solids and vessel surfaces makes sampling and analysis difficult. In Thorex pilot plant runs on short-decayed fuel, analyses of duplicate samples varied as much as $50 \%$ in protactinium content (12). Development work has been confined to laboratory studies with nonirradiated and fully irradiated fuel samples and small-scale engineering work. The true value of the new dissolution and solvent extraction methods remains to be demonstrated in a pilot plant on fully irradiated fuels.

The work reported in this paper was performed by many people at Oak Ridge National Laboratory. The authors acknowledge in particular the help of D. O. Campbell, A. T. Gresky, R. H. Rainey, and A. D. Ryon in preparing this paper.

*This paper was presented at the CNEN Symposium on Thorium Fuel Cycle, Sixth Nuclear Congress, June 13-15, 1961, Rome, Italy. 


\subsection{DISSOLUTION}

Two head-end processes for Thorex solvent extraction, Sulfex and Darex, have been developed on a laboratory and small engineering scale for dissolution of sintered $\mathrm{ThO}_{2}-\mathrm{UO}_{2}$ fuels clad in stainless steel $(1-6)$. In the Sulfex process the stainless steel clad is dissolved in boiling 4 to $6 \mathrm{M} \mathrm{H}_{2} \mathrm{SO}_{4}$ and in the Darex in boiling $5 \mathrm{M} \mathrm{HNO}_{3}-2 \mathrm{M} \mathrm{HCl}$. In both cases the sintered $\mathrm{ThO}_{2}-\mathrm{UO}_{2}$ fuel is dissolved in boiling $13 \mathrm{M} \mathrm{HNO}_{3}-0.04 \mathrm{M} \mathrm{NaF}-0.1 \mathrm{M} \mathrm{Al}\left(\mathrm{NO}_{3}\right)_{3}$. Experiments have shown that the Sulfex process will probably be satisfactory for decladding highly irradiated fuel elements but that in the Darex process losses of uranium to the solution would be excessive. Hence, combined dissolution of clad and core may be required if the Darex process is used.

\subsection{Stainless Steel Dissolution by the Sulfex Process}

In the Sulfex process, the stainless steel cladding is removed from the $\mathrm{ThO}_{2}-\mathrm{UO}_{2}$ fuel by dissolution in 3-fold the stoichiometric amount of boiling 4 to $6 \mathrm{M} \mathrm{H}_{2} \mathrm{SO}_{4}$ (Fig. 1). The off-gas is hydrogen, about 1.1 moles per mole $(55 \mathrm{~g})$ of stainless steel dissolved (3). The reactions are

$$
\begin{aligned}
\mathrm{Fe}+\mathrm{H}_{2} \mathrm{SO}_{4} & \longrightarrow \mathrm{FeSO}_{4}+\mathrm{H}_{2} \\
2 \mathrm{Cr}+3 \mathrm{H}_{2} \mathrm{SO}_{4} & \longrightarrow \mathrm{Cr}_{2}\left(\mathrm{SO}_{4}\right)_{3}+3 \mathrm{H}_{2} \\
\mathrm{Ni}+\mathrm{H}_{2} \mathrm{SO}_{4} & \longrightarrow \mathrm{NiSO}_{4}+\mathrm{H}_{2}
\end{aligned}
$$

The initial dissolution rate of type 304 stainless steel increases exponentially with sulfuric acid concentration (4): $\log$ rate $\left(\mathrm{mg} \mathrm{min}^{-1} \mathrm{~cm}^{-2}\right)=0.1915\left(\mathrm{H}_{2} \mathrm{SO}_{4}\right.$, M) -0.056 . Dissolution of a 20 - il -thick clad requires $1-3 \mathrm{hr}$. The solubility of stainless steel in sulfuric acid at $25^{\circ} \mathrm{C}$ decreases with increasing hydrogen ion concentration, from $80 \mathrm{~g}$ per liter at $5 \underline{\mathrm{N} \mathrm{H}} \mathrm{H}^{+}$to about $5 \mathrm{~g}$ per liter at $15 \mathrm{~N}$ $\mathrm{H}^{+}(1)$.

Passivation of stainless steel, from either protective oxide film formation or traces of nitric acid in the solution, is a potential problem. As little as $0.001 \mathrm{M} \mathrm{HNO}_{3}$ in the dissolvent can cause passivation $(3,6,13,14)$. Traces of nitric acid are readily removed by reaction with formic acid. However, with $0.02 \mathrm{M} \mathrm{HNO}_{3}$ present initially, 10-fold excess formic acid does not break passivation in $6 \mathrm{M} \mathrm{H}_{2} \mathrm{SO}_{4}$ in less than $1 \mathrm{hr}$. The time required to penetrate the passive oxide film decreases with increasing sulfuric acid concentration (14). With boiling $12 \mathrm{M} \mathrm{H}_{2} \mathrm{SO}_{4}$, passivation is broken almost immediately but the dissolver is severely corroded and in practice the sulfuric acid would be diluted to 4 to $6 \underline{M}$ as soon as passivation was broken. Another technique for breaking passivation is packing the fuel assembly with steel wool. Although 


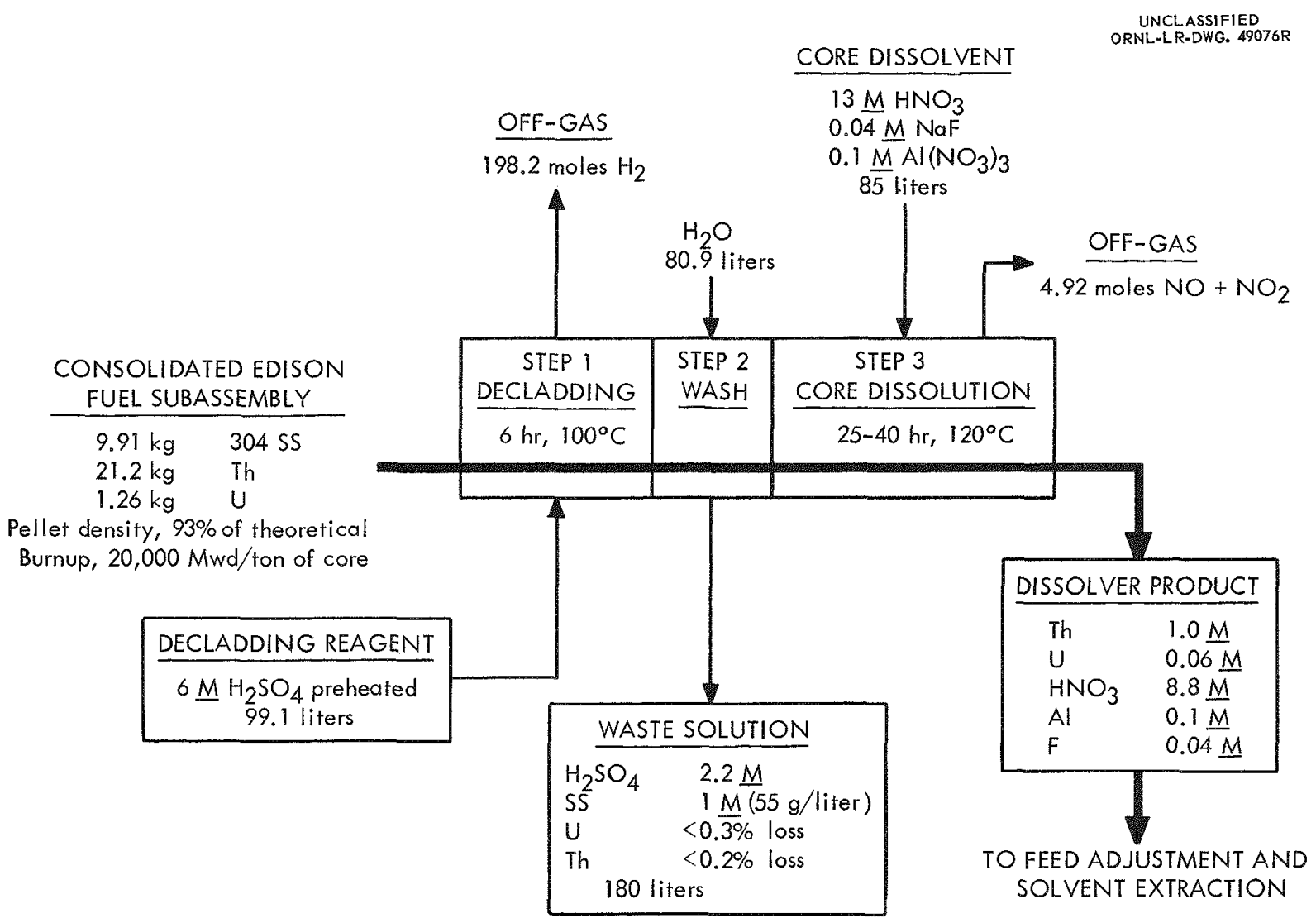

Fig. 1. Decladding and dissolution of Consolidated Edison reactor fuel by the Sulfex-Thorex process. 
passivation has been a problem with unbrazed fuel specimens, it is likely that no special attention will be required with brazed stainless steel specimens, which have consistently proved to be nonpassivated. Semicontinuous Sulfex decladding was successfully demonstrated in engineering-scale equipment (6) with unirradiated fuel (Sect. 1.5).

Losses of uranium to the decladding solution from high-density ( $>90 \%$ of theoretical) fuel specimens were generally less than $0.3 \%$ and were not greatly affected by burnup over the range 620 to $20,000 \mathrm{Mwd}$ per ton of core (Table la) $(5,15,16)$. The increase from $\sim 0.008 \% \cup$ loss with unirradiated fuels is artributed to the larger surface area present as the result of shattering of the highly irradiated fuel pellets (Fig. 2). With lower density fuel pellets, the uranium loss increased from 0.3 to $0.77 \%$ as the irradiation level increased from 0 to $200 \mathrm{Mwd}$ per ton of core. Thorium losses were generally less than $0.2 \%$. If desired, uranium in the decladding solution can be recovered by extraction with a primary amine in a hydrocarbon-alcohol diluent (17).

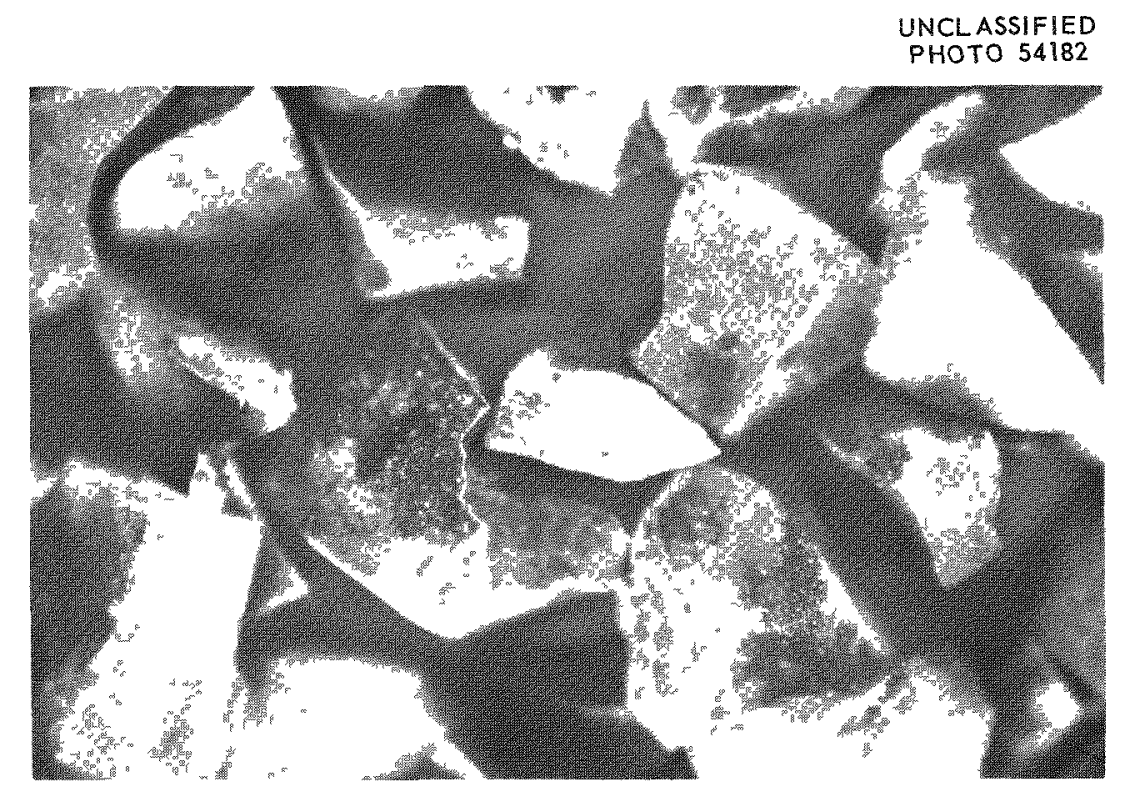

Fig. 2. Shattered fuel pellets from Sulfex run No. E-12 (19,600 Mwd per ton of core). Fragments $\sim 8-20$ mesh. 
Table 1. Uranium and Thorium Losses from Irradiated Consolidated Edison Fuel Specimens to Decladding Solutions

Samples: Sintered $\mathrm{ThO}_{2}-\mathrm{UO}_{2}$ pellets ( $0.26 \mathrm{in}$. dia, $0.5 \mathrm{in}$. high) encased in 20 -mil type $304 \mathrm{~L}$ stainless steel tubing

\begin{tabular}{lcccccc}
\hline \multicolumn{8}{c}{ Pellet Composition } \\
Pin & $\mathrm{UO}_{2}$, & $\mathrm{O} / \mathrm{U}$ & Density, & Burnup, Mwd/ton \\
No. & $\%$ & Ratio* & $\mathrm{g} / \mathrm{cc}$ & $\begin{array}{c}\text { of core } \\
\text { Time, hr }\end{array}$ & $\begin{array}{c}\text { Decladding } \\
\text { Losses, \% }\end{array}$ & $\begin{array}{c}\mathrm{U} \\
\text { Th }\end{array}$ \\
\hline
\end{tabular}

(a) Sulfex, 200\% excess boiling 4-6 $\mathrm{M} \mathrm{H}_{2} \mathrm{SO}_{4}$

\begin{tabular}{lrlrrrrr}
\hline$C-9$ & 9.1 & 2.0 & 9.5 & 0 & 16 & 0.008 & 0.01 \\
$C-15^{* *}$ & 9.1 & 2.0 & 9.5 & 620 & 8 & 0.07 & 0.04 \\
$C-16 * *$ & 6.5 & 2.0 & 9.5 & 740 & 5 & 0.26 & 0.18 \\
$C-17 * *$ & 6.5 & 2.0 & 9.1 & 6,000 & 3 & 0.03 & 0.03 \\
$C-18 * *$ & 6.5 & 2.0 & 9.1 & 12,000 & 3 & 0.30 & 0.29 \\
& & & & & & & \\
$E-12 * *$ & 4.2 & 2.0 & 9.5 & 19,000 & 3 & 0.09 & 0.02 \\
$E-16 * *$ & 4.2 & 2.0 & 9.5 & 14,500 & 3 & 0.16 & 0.03 \\
$C-19 * *$ & 6.5 & 2.0 & 9.1 & 16,600 & 3 & 0.16 & 0.04 \\
$C-2$ & 4.5 & 2.7 & $8.0-8.5$ & 0 & 3 & 0.31 & 0.05 \\
$A-117 * *$ & 5.0 & 2.7 & $8.0-8.5$ & 200 & 3 & 0.77 & 0.51 \\
\hline
\end{tabular}

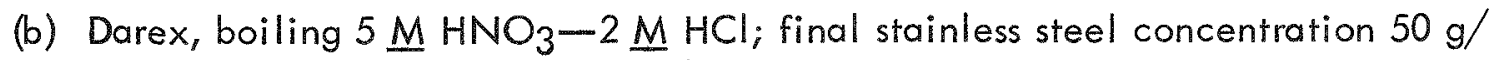
liter

\begin{tabular}{llllrrrl}
\hline$C-10$ & 9.1 & 2.0 & 9.5 & 0 & 15 & 0.15 & 0.008 \\
$C-11$ & 9.1 & 2.0 & 9.5 & 0 & 16 & 0.17 & 0.02 \\
$C-13^{* *}$ & 9.1 & 2.0 & 9.5 & 875 & 8 & 0.90 & 0.40 \\
$C-14^{* *}$ & 9.1 & 2.0 & 9.5 & 900 & 8 & 1.4 & 0.40 \\
$C-12 * *$ & 9.1 & 2.0 & 9.5 & 970 & 8 & 0.54 & 0.23 \\
& & & & & & & \\
$E-4 * *$ & 4.2 & 2.0 & 9.5 & 20,000 & 3 & 4.7 & -- \\
$E-6 * *$ & 4.2 & 2.0 & 9.5 & 20,000 & 3 & 4.6 & 0.12 \\
$E-21 * *$ & 4.2 & 2.0 & 9.5 & 14,000 & 3 & 3.3 & 0.20 \\
$C-20^{* *}$ & 6.5 & 2.0 & 9.1 & 11,000 & 3 & 2.0 & 0.16 \\
$E-22 * *$ & 4.2 & 2.0 & 9.5 & 21,800 & 3 & 3.2 & 0.09 \\
$C-3$ & 4.5 & 2.7 & $8.0-8.5$ & 0 & & & \\
$A-42 * *$ & 5.0 & 2.7 & $8.0-8.5$ & 190 & 1 & 2.1 & 1.1 \\
\hline
\end{tabular}

* The $O / U$ ratio indicates the uranium valence state assuming that the thorium is present as $\mathrm{ThO}_{2}$.

Fuel pellets shattered, 8-20 mesh (see Fig. 2). 


\subsection{Stainless Steel Dissolution by the Darex Process}

In the Darex process the stainless steel clad is dissolved in sufficient boiling $5 \mathrm{M} \mathrm{HNO}_{3}--2 \mathrm{M} \mathrm{HCl}$ to yield a solution containing about $50 \mathrm{~g}$ of stainless steel per liter (Fig. 3). The off-gas contains $2 \% \mathrm{~N}_{2} \mathrm{O}, 3 \% \mathrm{NO}, 20 \% \mathrm{NO}_{2}, 35 \% \mathrm{NOCl}$, $3 \% \mathrm{HCl}, 3 \% \mathrm{Cl}_{2}, 35 \% \mathrm{~N}_{2}$, and $0.2 \% \mathrm{H}_{2}(5,18)$. Although this concentration of hydrogen does not pose an explosion hazard, attention should be given to the composition of the gas after the acidic components are removed by caustic scrubbing because hydrogen in mixture with chlorine or $\mathrm{N}_{2} \mathrm{O}$ is potentially explosive over wide composition ranges (19). When stainless steel was dissolved in $\mathrm{HNO}_{3}-\mathrm{HCl}$ mixtures (total initial hydrogen ion concentration of $7 \mathrm{~N}$ ), the average hydrogen content of the off-gas increased from 0.15 to 2 vol \% as the $\mathrm{HCl}$ concentration increased from 2 to $6 \mathrm{~N}(5,20)$. Dissolution rates of stainless steel in boiling 4 and $6 \mathrm{M} \mathrm{HNO}_{3}$ reached maximums of 50 and $75 \mathrm{mg} \mathrm{min}^{-1} \mathrm{~cm}^{-2}$ when the $\mathrm{HCl}$ concentration was about $2 M(4,11,21)$. Dissolution of a 20 -mil-thick cladding requires about $1 \mathrm{hr}$ in boiling $5 \overline{\mathrm{M}} \overline{\mathrm{HNO}}_{3}-2 \mathrm{M} \mathrm{HCl}$.

The uranium loss to the Darex decladding solution was excessive with highly irradiated high-density fuel specimens containing 5 to $10 \% \mathrm{UO}_{2}$; the loss increased from 0.15 to $5 \%$ as the burnup increased from 0 to 20,000 Mwd per ton of core (Table 1b) $(5,15,16)$. While fragmentation of the core pellets undoubtedly contributed to the high Tosses, more dissolution of the uranium occurred than was expected from studies with powdered unirradiated specimens (1). For example, in a 3-hr contact, losses from the irradiated fragments $(8-20$ mesh) were about $3 \%$, whereas losses from - 100 mesh unirradiated material of about the same density were only about $0.5 \%$. Thorium losses generally were less than $0.4 \%$, even at the highest burnup. With lower density pellets the uranium loss increased from $\sim 0.63 \%$ to $\sim 2 \%$ as the irradiation level increased from 0 to $190 \mathrm{Mwd}$ per ton of core.

Semicontinuous Darex decladding was successfully demonstrated in engineering equipment with unirradiated fuel samples.

Uranium can be quantitatively recovered from the Darex decladding solutions, once they are freed of chloride, by direct extraction with $30 \%$ TBP in Amsco or as part of the first cycle acid Thorex process (Sect. 3.2) $(1,22)$. Total dissolution (clad and core) can be achieved by removing chloride from the decladding solution, adding the fluoride catalyst, and adjusting the acidity to $11 \mathrm{M}$ with $13 \mathrm{M} \mathrm{HNO} 3$ (Fig. 4).

\subsection{Aluminum Dissolution}

The aluminum cladding from $\mathrm{ThO}_{2}-\mathrm{UO}_{2}$ fuels such as the $\mathrm{BORAX}-\mathrm{IV}$ is readily dissolved in sodium hydroxide--sodium nitrate solutions with little loss of uranium or thorium (23). With simulated BORAX-IV fuel specimens, uranium 


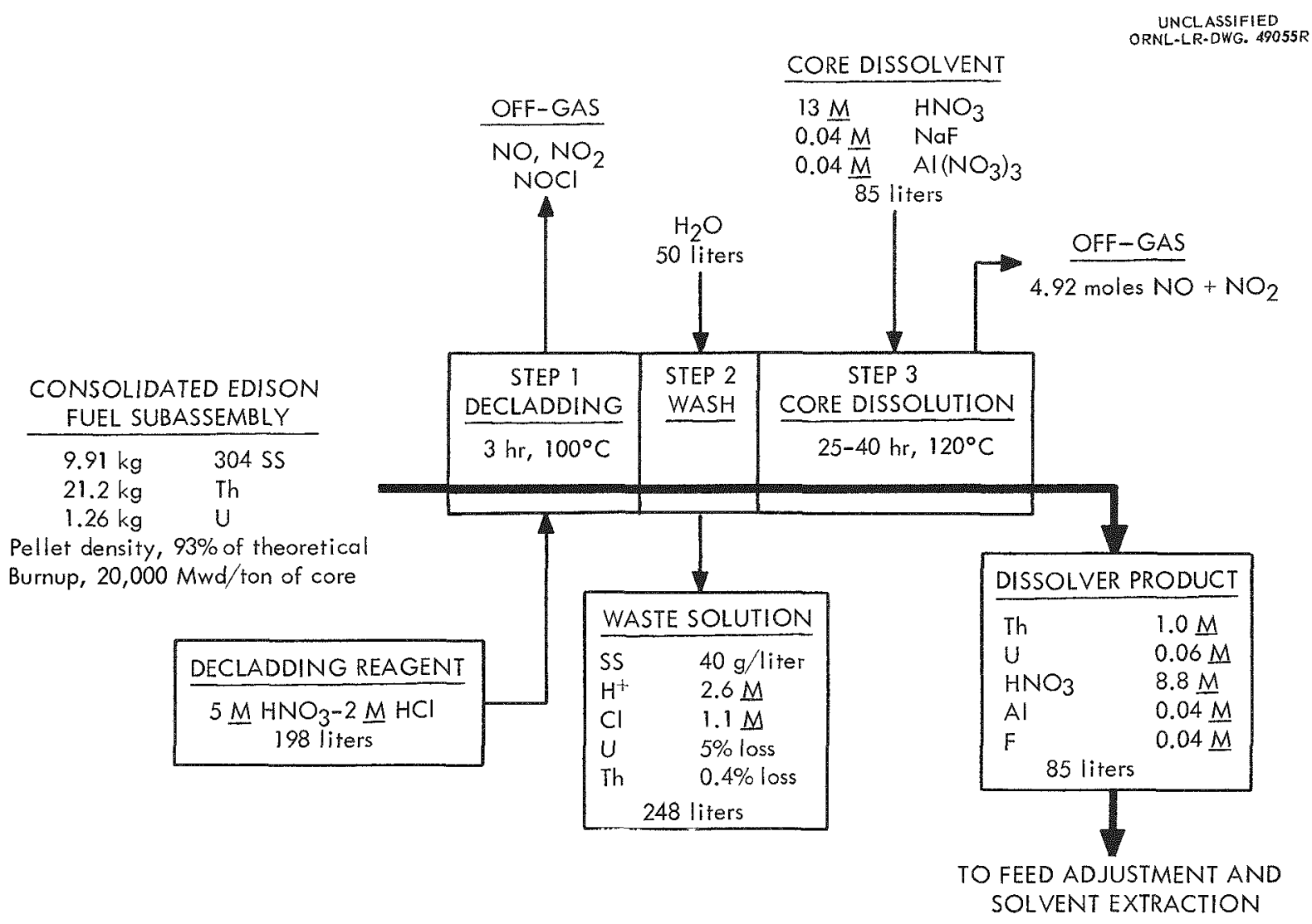

Fig. 3. Decladding and dissolution of Consolidated Edison reactor fuel by the Darex-Thorex process. 


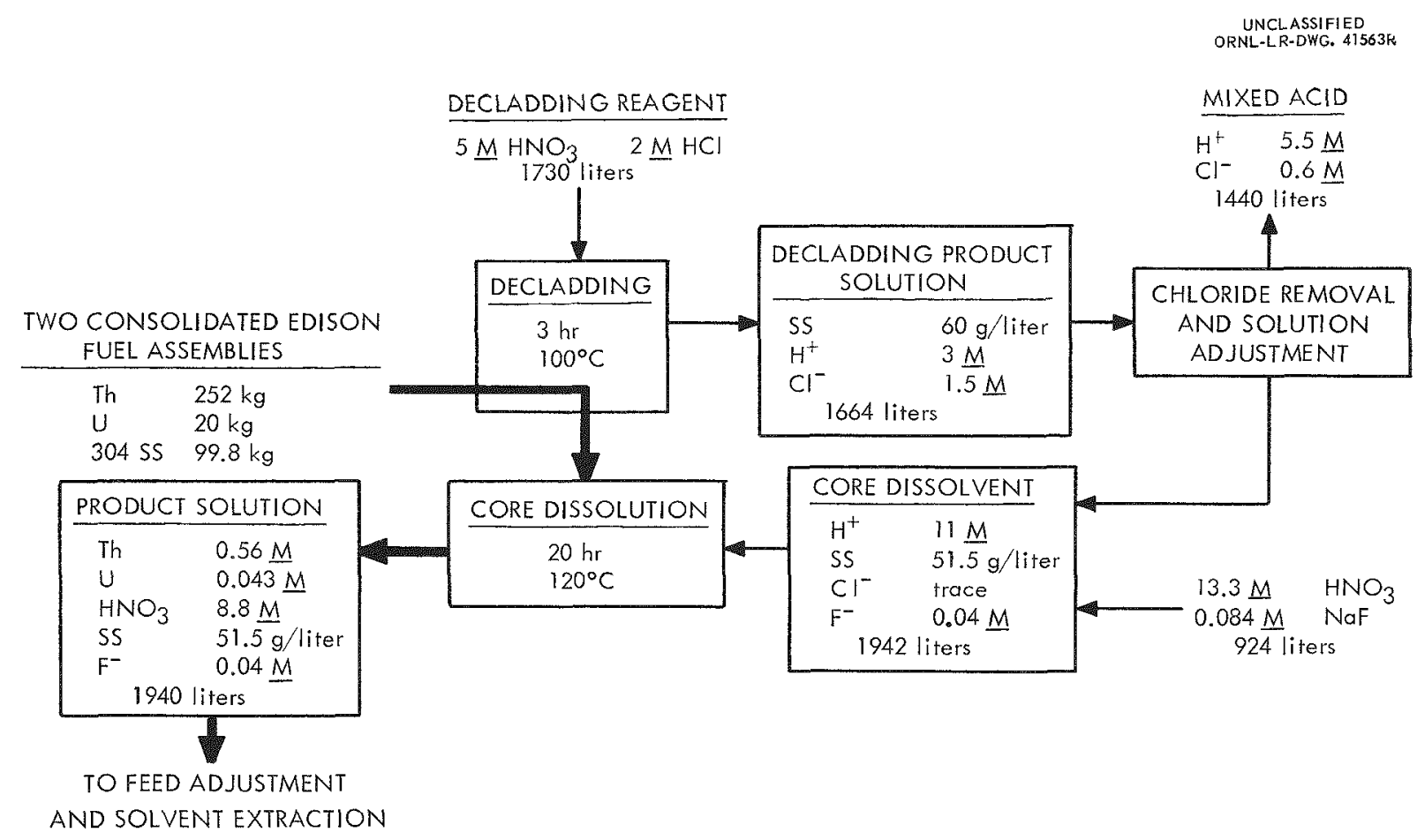

Fig. 4. Darex-Thorex flowsheet for total dissolution ot Consolidated Edison fuel. 
and thorium losses were less than 0.06 and $0.006 \%$, respectively, when the aluminum cladding was dissolved in boiling $2 \mathrm{M} \mathrm{NaOH}-1.78 \mathrm{M} \mathrm{NaNO}$. Dissolution of the aluminum cladding in mercury-catalyzed nitric acid resulted in uranium and thorium losses of about 0.6 and $0.1 \%$, respectively.

\subsection{Zirconium Dissolution}

Preliminary experiments with unirradiated fuel specimens $\left(4.2 \% \cup_{2} .7,83 \%\right.$ of theoretical density) indicated that the zirconium cladding could be dissolved in boiling $6 \mathrm{M} \mathrm{NH} \mathrm{N}_{4}-1 \mathrm{M} \mathrm{NH}_{4} \mathrm{NO}_{3}$ (Zirflex process) $(24,25)$ with uranium losses of about 0.18 and $0.36 \%$, respectively, in decladding times of 3 and $5 \mathrm{hr}$ (38).

\subsection{Core Dissolution}

$\mathrm{ThO}_{2}-\mathrm{UO}_{2}$ Fuel. The reagent most commonly used for dissolution of thorium, thorium oxide, and $\mathrm{ThO}_{2}-\mathrm{UO}_{2}$ mixtures is boiling nitric acid containing a fluoride catalyst. The dissolution rate of $\mathrm{ThO}_{2}-\mathrm{UO}_{2}$ mixtures depends on the nitric acid, fluoride, and thorium concentrations of the solution and the density and state of subdivision of the mixture. All other variables being constant, the rate is maximum when the nitric acid concentration is about $13 M(26)$ and when the fluoride ion concentration is about $0.06 \mathrm{M}$ (1). The instantaneous dissolution rate was decreased by a factor of about 5 as the thorium concentration increased from 0 to $0.9 \mathrm{M}(11,26)$.

Dissolution rates of sintered $\mathrm{ThO}_{2}-4.4 \mathrm{UO}_{2}$ pellets with a density of $9.5 \mathrm{~g} / \mathrm{cc}$ in solutions containing $0.04 \mathrm{~N} \mathrm{NaF}$ were correlated (16) by

$R=0.627\left(\frac{M_{H N O}}{10}\right)^{3}-0.336\left(\frac{M_{H N O}}{10}\right)^{4}-0.12\left(\frac{\frac{M_{H N O}}{10}}{10}\right)^{3} \underline{M}_{\mathrm{Th}}$

where $R=$ reaction rate, $\mathrm{mg} \mathrm{g}^{-1} \mathrm{~min}^{-1}$

$\underline{M}_{\mathrm{HNO}_{3}}=$ molarity of nitric acid in dissolvent

$\underline{M}_{T h}=$ molarity of thorium in dissolvent

As pellets dissolve, penetration is not uniform; roughness and porosity increase with an attendant increase in both the surface/weight ratio and dissolution rate. Therefore correlations using initial dissolution rates are valid only for whole pellets, and the effect of partial dissolution must be evaluated separately. In a plot of dissolution rate vs. fraction dissolved (Fig. 5), it was expected that the dissolution rate would rise continuously and sharply as $100 \%$ dissolution was approached since the 


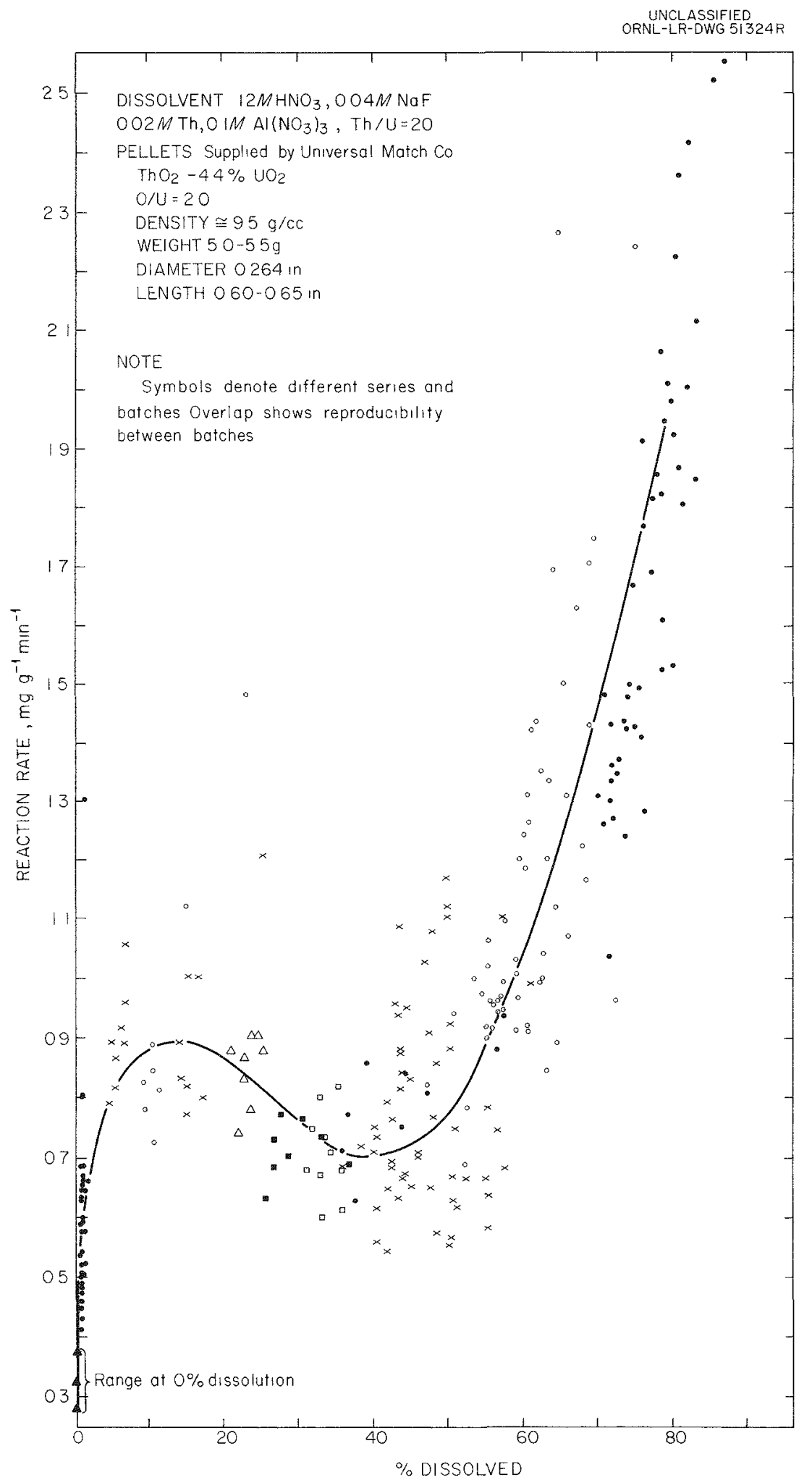

Fig. 5. Reaction rate of single $\mathrm{UO}_{2}--\mathrm{ThO}_{2}$ pellets as a function of fraction dissolved. 
surface/weight ratio increases greatly. However, an intermediate maximum rate in the $10-15 \%$ range was observed. The cause of this phenomenon is not clear, but it may be due to the early release of small particles of $\mathrm{ThO}_{2}-\mathrm{UO}_{2}$ from the pellet surface. Dissolution rates for whole pellets and $50 \%$ dissolved pellets in $12 \mathrm{M} \mathrm{HNO} 3-$ $0.04 \mathrm{M} \mathrm{NaF}-0.1 \mathrm{M} \mathrm{Al}\left(\mathrm{NO}_{3}\right)_{3}-0.2 \mathrm{M} \mathrm{Th}\left(\mathrm{NO}_{3}\right)_{4}-0.01 \mathrm{MUO}_{2}\left(\mathrm{NO}_{3}\right)_{2}$ varied from 0.28 to $0.37 \mathrm{mg} \mathrm{g}^{-1} \mathrm{~min}^{-1}$ and for $50 \%$ dissolved pellets, from 0.54 to 1.17 $\mathrm{mg} \mathrm{g}^{-1} \min ^{-1}$.

The dissolution rate of $\mathrm{ThO}_{2}-5 \% \mathrm{UO}_{2}$ pellets is inversely proportional to their densities. In boiling $13 \mathrm{M} \mathrm{HNO}_{3}-0.04 \mathrm{M} \mathrm{NaF}-0.1 \mathrm{MAl}\left(\mathrm{NO}_{3}\right)_{3}$, the initial rate of dissolution decreased from 18 to about $2 \mathrm{mg} \mathrm{min}^{-1} \mathrm{~cm}^{-2}$ as the density of the pellets increased from 60 to $90 \%$ of theoretical (Fig. 6) (1). In 200\% stoichiometric excess of this reagent, $25-40 \mathrm{hr}$ is required to dissolve completely $0.26-$ in.-dia pellets which are $90-95 \%$ of theoretical density. Powdering of ThO2- $\mathrm{UO}_{2}$ mixtures greatly increases the rate of dissolution; for example, the percentage of $\mathrm{ThO}_{2}-4.2 \% \mathrm{UO}_{2} .6$ fuel ( $94 \%$ of theoretical density) dissolved in $5 \mathrm{hr}$ in $200 \%$ stoichiometric excess of boiling $13 \mathrm{M} \mathrm{HNO}_{3}-0.04 \mathrm{M} \mathrm{NaF-}-0.1 \mathrm{MAl}\left(\mathrm{NO}_{3}\right)_{3}$ increased from about 70 to 99 as the particle size was decreased from 4 mesh to less than 100 mesh (1). The fragmented cores (8-20 mesh) from the irradiated specimens (Table 1) dissolved at about the same rate as unirradiated material of the same particle size and density.

Aluminum nitrate, added to the dissolvent to inhibit the corrosive action of the fluoride catalyst, has a slightly deleterious effect on the dissolution rate. Increasing the aluminum concentration from 0 to $0.2 \mathrm{M}$ caused about a $20 \%$ reduction in the dissolution rate $(1,4)$. Within experimental error, the presence of up to $10 \% \mathrm{UO}_{2}$ in a $\mathrm{ThO}_{2}-\mathrm{UO}_{2}^{-}$mixture had no effect on the dissolution rate (27). The valence state of the uranium also had little or no effect on the rate of dissolution.

Chemical effects of the addition of soluble neutron poisons such as boron or cadmium to process solutions to aid in criticality control were considered. The presence of up to $0.1 \mathrm{M} \mathrm{H}_{3} \mathrm{BO}_{3}$ or $0.075 \mathrm{M} \mathrm{Cd}\left(\mathrm{NO}_{3}\right)_{2}$ in boiling $13 \mathrm{M} \mathrm{HNO}_{3}-$ $0.04 \mathrm{M} \mathrm{NaF}-0.1 \mathrm{MAI}\left(\mathrm{NO}_{3}\right)_{3}$ had little effect on the rate of dissolution of $\mathrm{ThO}_{2}-$ $5 \% \overline{U O}_{2}$ pellets which were about $94 \%$ of theoretical density (27).

In the Sulfex-Thorex process it is important that the $\mathrm{ThO}_{2}-\mathrm{UO}_{2}$ core be carefully washed after the decladding step. The presence of $0.1 \mathrm{M}$ sulfate in the dissolvent decreases the amount of core dissolved in $1 \mathrm{hr}$ from 32 to $6.5 \%(1,4)$. Apparently, an impervious coating of thorium sulfate forms on the surface of the core pellets but is easily removed by water-washing. 

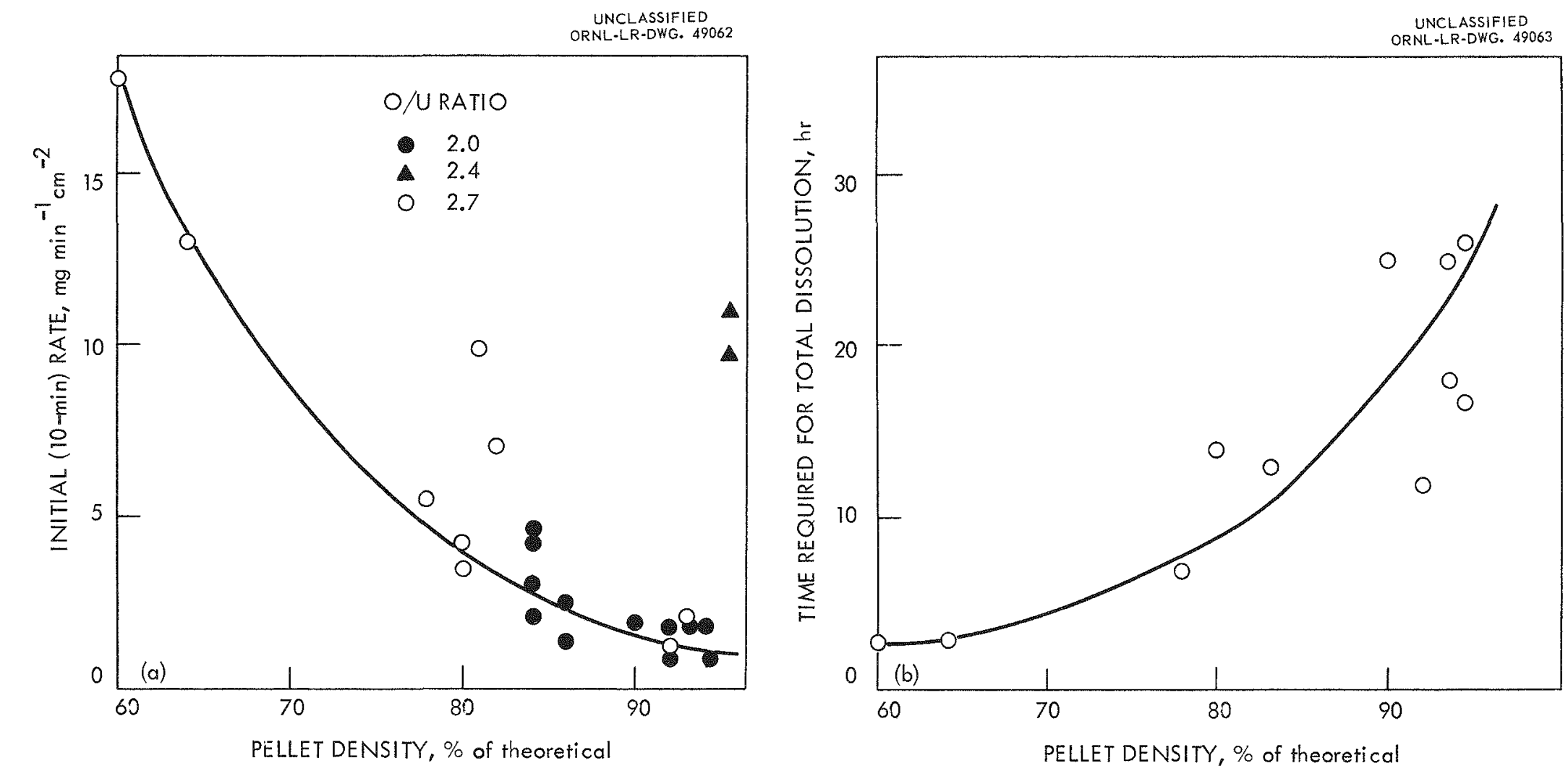

Fig. 6. Effect of pellet density on (a) initial (10-min) rate of dissolution and (b) total dissolution time for $95 \%$ $\mathrm{ThO}_{2}-5 \% \mathrm{UO}_{2}$ pellets in $200 \%$ excess of boiling $13 \mathrm{M} \mathrm{HNO}_{3}-0.04 \mathrm{M} \mathrm{NaF--0.1} \mathrm{M} \mathrm{Al}\left(\mathrm{NO}_{3}\right)_{3}$. 
In actual practice, both decladding and core dissolution will probably be semicontinuous, i.e., batch addition of fuel and continuous addition of dissolvent, so that geometrically or near geometrically safe dissolvers can be used (Sect. 5.0). Small-scale engineering tests (6) of semicontinuous dissolution of unirradiated pellets by the Sulfex and Darex processes were successfully carried out in 4-in.dia $\times$ 19-ft-high and 1-in.-dia $\times$ 0.5-ft-high dissolvers, respectively. The decladding solution was metered to the dissolver and contacted the cladding only once. All the core dissolvent was added initially and was recirculated around a dissolver-receiver tank circuit. In the Darex tests the decladding time was about $\mathrm{I} \mathrm{hr}$ with no evidence of passivation. These experiments also showed the feasibility of operating with a $10 \%$ heel, i.e., $10 \%$ of the core remaining in the dissolver when the next batch of fuel is added. Results of a four-cycle run showed that the Th/U mole ratio in the fuel solution remained constant, and the uranium loss to the decladding solution with a $10 \%$ oxide heel from the previous core dissolving was about $0.1 \%$ In four cycles, the accumulated heel did not exceed $10 \%$ of the amount of fuel charged per cycle. Each core dissolution period was $8 \mathrm{hr}$ (Table 2a).

In the Sulfex tests the stainless steel was passive to the boiling $4 \mathrm{M} \mathrm{H}_{2} \mathrm{SO}_{4}$ in the second and third cycles, but draining of this acid and admission of fresh acid overcame passivity immediately, presumably by elimination of residual nitric acid. In the fourth cycle, the $\mathrm{H}_{2} \mathrm{SO}_{4}$ was made $0.1 \mathrm{M}$ in $\mathrm{HCOOH}$, and dissolution started immediately. Decladding times varied from 3 to $4 \mathrm{hr}$. Uranium and thorium losses were less than 0.1 and $0.25 \%$, respectively, and core dissolution times were approximately $10 \mathrm{hr}$ in each run. The core dissolvent was recirculated until the densities of the solutions entering and leaving the dissolver were equal. Unlike the Darex experiments, in which the heel remained fairly constant, the amount of heel increased over four cycles to about $20 \%$ of the total $\mathrm{ThO}_{2}-\mathrm{UO}_{2}$ charged per cycle. At the end of the fourth cycle, a 24-hr heel cleanout with fresh dissolvent was made, after which only $0.02 \%$ of the $\mathrm{ThO}_{2}-\mathrm{UO}_{2}$ charged over the four cycles remained (Table $2 b$ ).

Graphite-base Fuels. Three potential methods for processing graphite-base fuels are being developed: grind-leach ( $\left.70 \% \mathrm{HNO}_{3}\right)$ (39), disintegration-leach $\left(90 \% \mathrm{HNO}_{3}\right)(40)$, and combustion-dissolution. While the grind-leach process is applicable to virtually all types of graphite-base fuels proposed, uranium and thorium losses to the undissolved matrix are generally higher than desired. For example, in leaching of -16 mesh graphitized fuel specimens containing $1-2 \%$ uranium and $7-14 \%$ thorium with boiling $13 \mathrm{M} \mathrm{HNO}_{3}-0.04 \mathrm{M} \mathrm{NaF}-0.04 \mathrm{M}$ $\mathrm{Al}\left(\mathrm{NO}_{3}\right)_{3}$ uranium and thorium losses are usually about $10 \%$. Since the newer fuels containing $\mathrm{Al}_{2} \mathrm{O}_{3}$-coated fuel particles cannot be processed by either the $90 \% \mathrm{HNO}_{3}$ or the combustion-dissolution processes, the grind-leach process probably will receive considerably more development in an effort to improve uranium and thorium recoveries. 
Table 2. Sulfex-Thorex Cyclic Runs in 4-in.-dia Engineering-scale Dissolver Cladding: 20-mil-thick 304 stainless steel

$\mathrm{ThO}_{2}-\mathrm{UO}_{2}$ pellets: $90-95 \%$ of theoretical density, $0.26 \mathrm{in}$. dia

Fuel charged in batches; dissolvent circulated for both decladding and dissolution

\begin{tabular}{|c|c|c|c|c|c|c|c|}
\hline \multirow{2}{*}{ Cycle } & \multirow{2}{*}{\multicolumn{2}{|c|}{$\mathrm{ThO}_{2}-\mathrm{UO}_{2}, \%$}} & \multicolumn{2}{|c|}{$\begin{array}{l}\text { Final Product } \\
\text { Conc, g/liter }\end{array}$} & & \multirow{2}{*}{$\begin{array}{c}\text { Dissolution } \\
\text { Rate, } \\
\min ^{-1} \mathrm{~cm}^{-2}\end{array}$} & \multirow{2}{*}{$\begin{array}{l}\text { Decladding } \\
\text { Loss, } \%\end{array}$} \\
\hline & & & $\begin{array}{l}\text { Stainless } \\
\text { Steel }\end{array}$ & Th & u & & \\
\hline \multicolumn{8}{|c|}{ (a) Darex-Thorex, 1-in.-dia Dissolver } \\
\hline Ist decladding & & & 62 & & & 17.0 & 0.11 \\
\hline Ist core dissoln. & 93.6 & 6.4 & & 166 & & 2.82 & \\
\hline 2nd decladding & & & 64 & & & 17.2 & 0.09 \\
\hline 2nd core dissoln. & 92.2 & 7.8 & & 155 & & 2.67 & \\
\hline 3rd decladding & & & 59 & & & 19.4 & 0.04 \\
\hline 3rd core dissoln. & 91.0 & 9.0 & & 156 & & 2.65 & \\
\hline 4th decladding & * & * & & * & & * & * \\
\hline 4th core dissoln. & 90.7 & 9.3 & & 158 & & 2.74 & \\
\hline
\end{tabular}

(b) Sulfex-Thorex, 4-in.-dia Dissolver

Ist decladding

26.9

$2.27 \quad 0.0220 .017$

1st core dissoln.

$89.5 \quad 10.5$

2nd decladding

35

2nd core dissoln.

$91.2 \quad 8.8$

3rd decladding

33.3

3rd core dissoln.

$86 \quad 14$

$\begin{array}{lll}83 & 4.5 & 1.9\end{array}$

4 th decladding

4th core dissoln.

$80 \quad 20$

26

$\begin{array}{lll}126 & 6.8 & 1.9\end{array}$

$1417.6 \quad 2.2$

Heel cleanout

$99.2 \quad 0.02$

(24 hr)

* No data. 
The disintegration-leach process $(40)$ is a simple method for simultaneous disintegration and leaching of graphite-base fuels. Uranium and thorium recoveries are generally $>99 \%$ when the fuels are not coated or do not contain coated fuel particles. The method is applicable to noncoated fuels containing more than $1 \%$ uranium and/or thorium, but multiple leaching with boiling acid is required to effect high recoveries from the thorium-bearing fuels. Experiments with slightly irradiated uranium-graphite fuel samples indicated that about $50 \%$ of the longlived fission products will remain with the graphite residue even when the uranium is essentially quantitatively leached. The $90 \% \mathrm{HNO}_{3}$ process, without modification, cannot be used with fuels containing coated fuel particles, including pyrolytic graphite-coated fuel, and does not disintegrate unfueled graphite.

Uranium and thorium recoveries from graphite-base fuels by the combustiondissolution (13 $\mathrm{M} \mathrm{HNO} 3-0.04 \mathrm{M} F-0.04 \underline{\mathrm{M} \mathrm{Al}}$ ) process are generally $>99 \%$ except when the fuel particles are coated with $\mathrm{Al}_{2} \mathrm{O}_{3}$. Zirconium carbide-, beryllium oxide-, and silicon carbide-coated particle fuels remain to be tested. Experiments with slightly irradiated uncoated fuel specimens indicate that most of the Ru-106 is volatilized during combustion. Rough crushing of fuel bodies coated with $\mathrm{Al}_{2} \mathrm{O}_{3}, \mathrm{SiC}$, or $\mathrm{ZrC}$ will probably be required before combustion. Some loss of uranium and thorium to the ash is expected when the fuel body is coated.

Beryllium Oxide-base Fuel. A suitable process has not yet been developed for dissolving $\mathrm{BeO}$-base fuels, particularly when $\mathrm{ThO}_{2}$ is present. The uranium can be leached from $\mathrm{UO}_{2}-\mathrm{BeO}$ fuel pellets with boiling 6 to $13 \mathrm{M} \mathrm{HNO}_{3}$ when the $\mathrm{UO}_{2}$ content is higher than about $60 \%(41)$. BeO-UO2 mixtures containing up to $10 \%$ $\mathrm{UO}_{2}$ can be dissolved only in boiling 55-60\% $\mathrm{H}_{2} \mathrm{SO}_{4}$ and 6-10 $\mathrm{M} \mathrm{NH}_{4} \mathrm{HF}_{2}$ solutions; the dissolution rates are of the order of 1 to $3 \mathrm{mg} \mathrm{min}^{-1} \mathrm{~cm}^{-2}$. These solutions are extremely corrosive to common materials of construction. The presence of thorium probably will make the dissolution even more difficult because of its insolubility in sulfate and fluoride solutions.

BeO-base fuels can be dissolved with HF in molten fluoride fused salts and the uranium recovered by fluorination (42). Thorium would not be recoverable by the fluoride volatility process unless a separate isolation procedure was developed.

Beryllide Fuel. Work on the dissolution of UBe 13-ThBe 13 fuels has not yet been started at Oak Ridge National Laboratory. However, there seems to be ample evidence, based on analytical procedures, that these materials dissolve rapidly in boiling Thorex reagent, $13 \mathrm{M} \mathrm{HNO}_{3}-0.04 \mathrm{M} \mathrm{NaF}$ and in dilute nitric acid. 


\subsection{SOLVENT EXTRACTION}

New feed adjustment and solvent extraction techniques have been developed to correct deficiencies in the original aluminum-salted Thorex process $(9,10)$. These include steam stripping to reduce corrosion during feed adjustment, the use of $\mathrm{HNO}_{3}$ instead of $\mathrm{Al}\left(\mathrm{NO}_{3}\right)_{3}$ as a salting agent, bisulfate complexing to increase decontamination from ruthenium, and solvents other than tributyl phosphate. Perhaps the most significant improvement is the elimination of $\mathrm{Al}\left(\mathrm{NO}_{3}\right)_{3}$ in the new acid Thurex process, which permits a tenfold additional decrease in waste volume and a $50 \%$ decrease in pulsed column stage height while maintaining decontamination factors and thoriumuranium recoveries equal to or better than those obtained with $\mathrm{Al}\left(\mathrm{NO}_{3}\right)_{3}$ salting.

\subsection{Feed Adjustment}

Both the aluminum and acid Thorex processes require an acid deficient feed to achieve high decontamination, and the free acid and part of the acid from hydrolysis must be removed. The previous method $(9,10)$ for acid removal was to evaporate the solution to $155^{\circ} \mathrm{C}$. Limitations of this method include a high corrosion rate and the difficulties involved in mixing and sampling a molten salt. A new procedure has been demonstrated (22) in small-scale equipment in which the dissolver solution is concentrated to $\sim 135^{\circ} \mathrm{C}$ and then steam stripped at this temperature to remove additional acid (Fig. 7). Following acidity adjustment by steam stripping, the feed is made $0.1 \mathrm{M}$ in $\mathrm{NaHSO}_{3}$ to convert ruthenium to a nonextractable form.

In processing of long-decayed fuel (1500 g U-233/ton, cooled 200 days) in a pilot plant, decontamination factors were satisfactory from ruthenium ( 600$)$ and $\mathrm{Zr}-\mathrm{Nb}\left(\sim 3 \times 10^{3}\right)$ in the extraction column as the result of conversion of these fission products to nonextractable species during the high-temperature $\left(155^{\circ} \mathrm{C}\right)$ acid deficient feed adjustment step (9). However, with highly active solutions (3500 g U-233/ton, decayed 30 days) the ruthenium was reconverted to an extractable form, probably by the reaction with nitrite produced by radiolysis of nitrate, and the ruthenium decontamination factor was only about 2 in the first cycle. In laboratory studies, heating the acid deficient thorium solutions to $50^{\circ} \mathrm{C}$ with $0.02 \mathrm{~N} \mathrm{NaHSO} 3$ reconverted the ruthenium to a nonextractable form (28). Decontamination factors from ruthenium were $\sim 300$ in experiments with full-activitylevel short-decayed acid deficient aluminum-salted Thorex feed. These results were confirmed in a pilot plant test with diluted short-decayed feed containing nitrite. Decontamination from ruthenium $\left(\sim 10^{3}\right)$ was also high with $\mathrm{NaHSO}_{3}$ reduction in laboratory-scale experiments under acid Thorex conditions. 
ORNL-LR-DWG. 53206

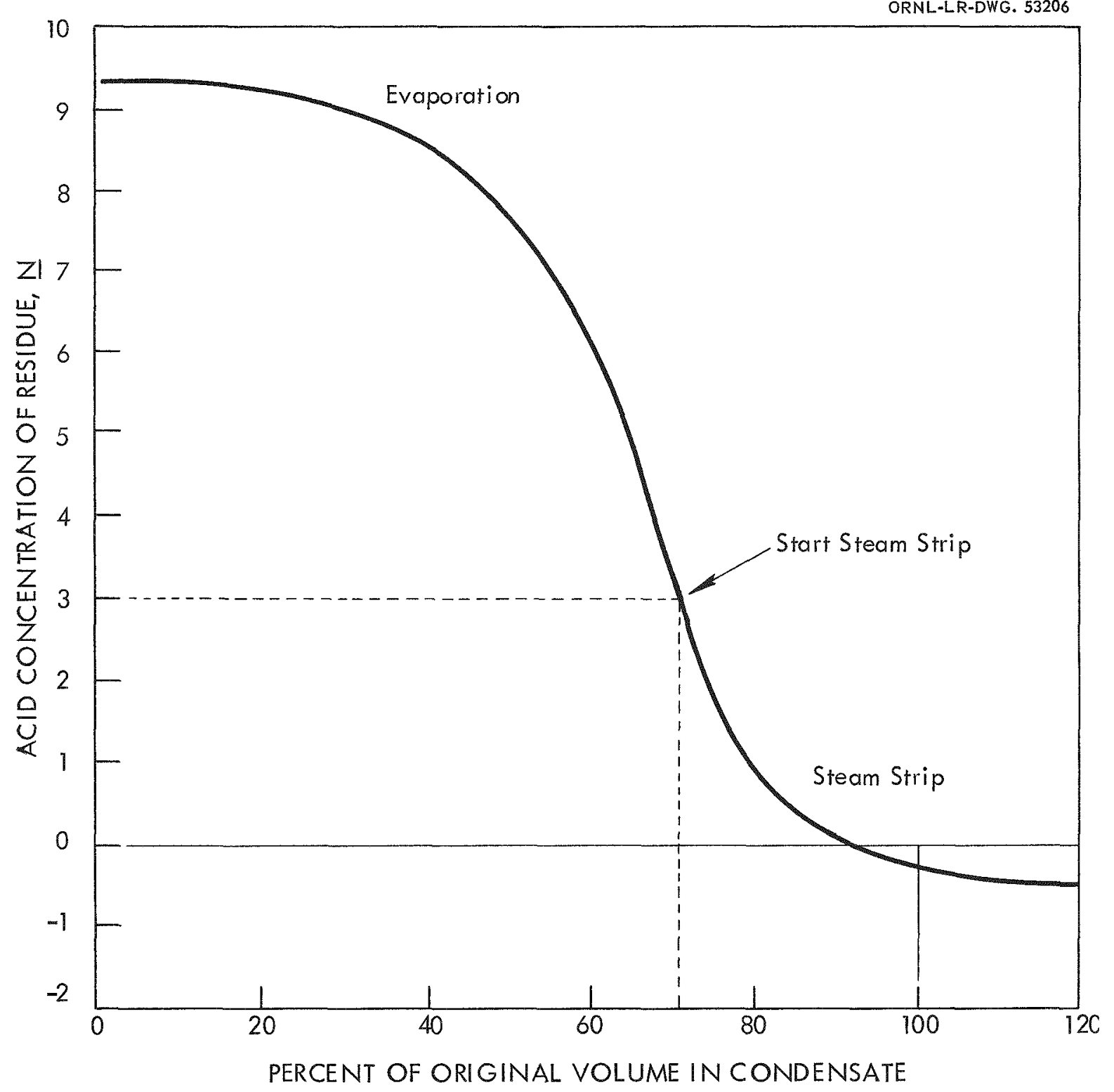

Fig. 7. Evaporation and steam stripping of simulated Consolidated Edison core solution for solvent extraction feed. 
The chemical compatibility of certain soluble nuclear poisons, viz., cadmium, samarium, and gadolinium, with process solutions was demonstrated in laboratory experiments (29). These materials did not volatilize significantly, i.e., $<6 \%$, and did not precipitate during the steam stripping.

\subsection{Acid Thorex Process (7)}

In the first cycle, the adjusted feed contains $265 \mathrm{~g}$ of thorium and $15 \mathrm{~g}$ of uranium per liter, $0.115 \mathrm{M} \mathrm{Al}^{3+}, 0.046 \mathrm{MF}^{-}, 0.1 \mathrm{M} \mathrm{NaHSO}_{3}$, and is $0.15 \pm 0.05 \mathrm{M}$ acid deficient. The feed is contacted with $30 \%$ TBP and scrubbed with nitric acid to coextract thorium and uranium in the first column (Fig. 8). The extract is scrubbed in the first column with $\mathrm{HNO}_{3}$ and $\mathrm{H}_{3} \mathrm{PO}_{4}$ and $\mathrm{Fe}\left(\mathrm{NH}_{2} \mathrm{SO}_{3}\right)_{2}$ to decrease extraction of fission products, protactinium, and $\mathrm{CrO}_{4}$ (from corrosion of stainless steel), respectively. The thorium is partitioned from uranium in the second column with $0.008 \mathrm{M}$ $\mathrm{Al}\left(\mathrm{NO}_{3}\right)_{3}$, and the uranium is stripped from the solvent with $0.008 \mathrm{M} \mathrm{Al}\left(\mathrm{NO}_{3}\right)_{3}$ in the third column. The thorium and uranium are each processed through an extraction cycle for sufficient additional decontamination to ensure that the fission product activities are not greater than the U-232 daughter activities.

During extraction the acid deficient feed condition maintains the fission products as nonextractable species. High distribution coefficients for uranium and thorium are provided at the feed point by thorium salting, and near the bottom of the column, where the thorium concentration is low, by nitric acid addition. Decontamination is maximum with a scrub of $1 \mathrm{M} \mathrm{HNO}_{3}$; the scrub addition is split to prevent nitric acid carryover to the partitioning column. Under these conditions decontamination factors were 103,8 $\times 10^{3}, 10^{3}$, and $2 \times 10^{5}$ for ruthenium, zirconiumniobium, protactinium, and rare earths, respectively, in countercurrent batch extraction tests. Alternatively, chloride-free stainless steel-bearing Darex decladding solution can be added at the fourth extraction stage to recover uranium and thorium (22) (Sect. 2.2).

In the improved thorium-uranium partitioning step, $<0.1 \%$ of the uranium is lost to the thorium and $<0.1 \%$ of the thorium to the uranium in the partitioning column in 10 theoretical stages by minimizing the volume and the acid in the thorium strip solution and by decreasing the scrub volume. Operating flow ratios for the partitioning column were calculated from a McCabe-Thiele graphical solution based on equilibrium distribution data for thorium and uranium (30). Five stages each of scrubbing and stripping are used. The flow capacity of the new Thorex process is governed by flooding in the scrubbing section of the partitioning column, which occurs at $750 \mathrm{gal} \mathrm{hr}^{-1} \mathrm{ft}^{-2}$ at $1 \mathrm{in}$. pulse amplitude and $50 \mathrm{cpm}$.

The uranium is stripped in the third column with $0.008 \mathrm{M} \mathrm{Al}\left(\mathrm{NO}_{3}\right)_{3}$ in five theoretical stages. An alternative stripping operation was demonstrated (16) in which the uranium product concentration is increased by refluxing and by withdrawal at a point between the partitioning and stripping columns. In this case, 


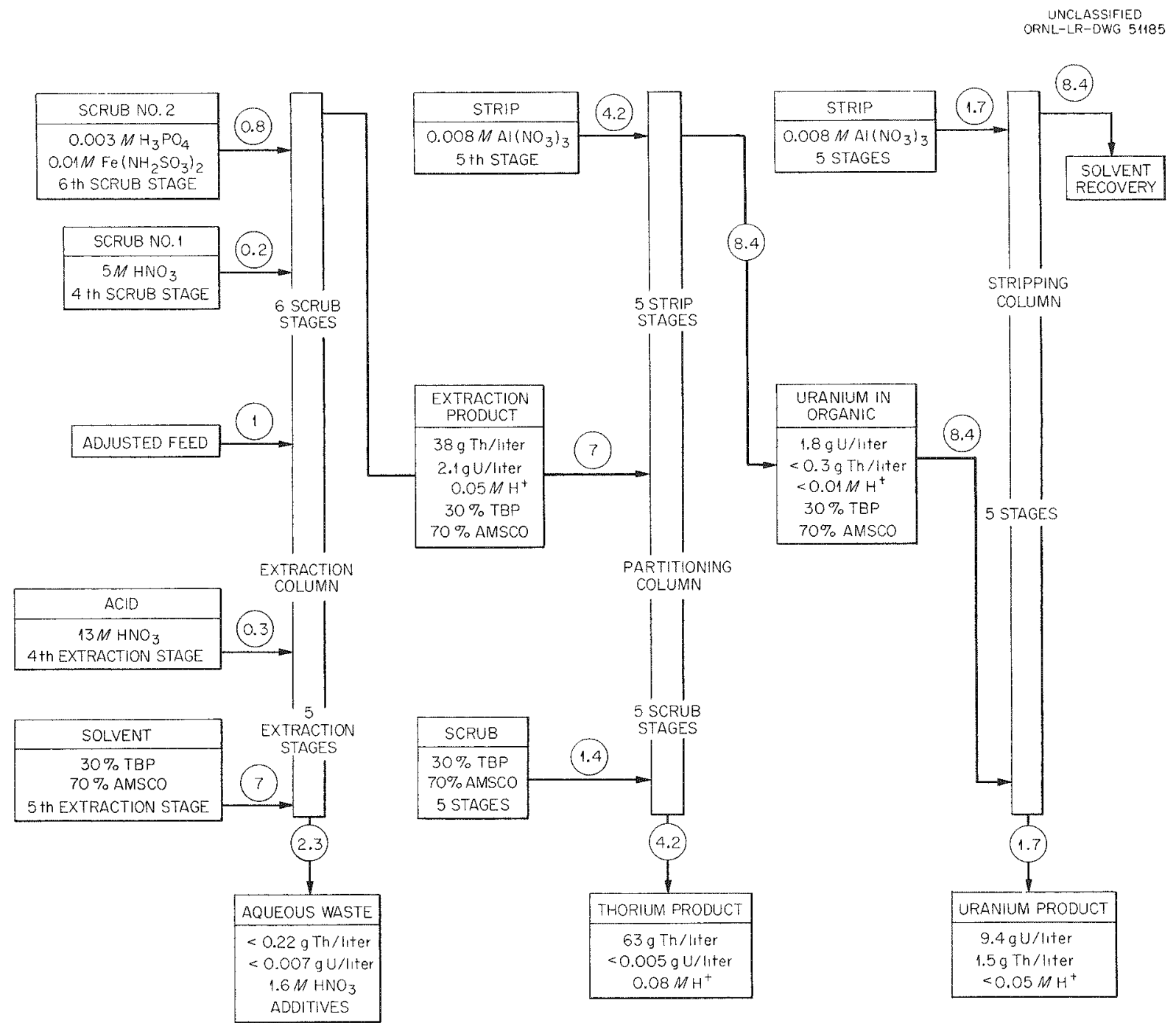

Fig. 8. Acid Thorex flowsheet for Consolidated Edison fuel. 
part of the aqueous stream from the third column is returned as stripping agent for thorium to the partitioning column; the remainder is withdrawn as uranium product. The uranium concentration builds up to a maximum in the upper section of the partitioning column where the thorium concentration is low. Further down the column, thorium salting causes extraction of the uranium, preventing loss out the bottom. With a $24 \mathrm{ft}$ sieve-plate stripping column at a feed/scrub/recycle/product flow ratio of 1.0/0.15/0.48/0.15, the uranium concentration increased to $20 \mathrm{~g} /$ liter, more than twice that without reflux. The loss of uranium to the thorium product was $0.054 \%$ and $<0.002 \%$ to the stripped solvent; thorium loss to the uranium product was $0.03 \%$.

Distribution coefficients obtained in batch extraction tests indicated low extraction of nuclear poisons such as cadmium, samarium, and gadolinium from nitrate solutions by TBP in Amsco (29). Single-cycle countercurrent batch extractions with the acid Thorex flowsheet gave uranium decontamination factors from boron, cadmium, and rare earths of $>10^{4},>1.5 \times 103$, and $>104$, respectively. Countercurrent batch extractions with 2.5\% TBP in Amsco resulted in concentrations of boron, rare earths, and cadmium in the uranium product which were at the limits of analytical detection, i.e., 2.5, $<4$, and $<17$ ppm, respectively. Two extraction cycles should decrease the concentration of the nuclear poisons to acceptable levels for fuel recycle.

Engineering capacity and efficiency data are summarized in Table 3 (16).

If the recovery of thorium is not desired, a variation of the acid Thorex flowsheet may be used to selectively extract uranium (4). In countercurrent laboratory experiments the following flowsheet conditions gave decontamination factors of $5 \times 105,1.5 \times 105$, and $3.5 \times 105$, respectively, from ruthenium, zirconium, and rare earths.

Feed: $0.084 \mathrm{MUO}_{2}\left(\mathrm{NO}_{3}\right)_{2}, 1.5 \mathrm{M} \mathrm{Th}\left(\mathrm{NO}_{3}\right)_{4}, 0.16 \mathrm{M} \mathrm{HNO} 3,1$ vol Scrub: $5 \mathrm{M} \mathrm{HNO}, 0.01 \mathrm{M} \mathrm{Fe}\left(\mathrm{NH}_{2} \mathrm{SO}_{3}\right)_{2}, 0.003 \mathrm{M} \mathrm{H} \mathrm{PO}_{4}, 0.4 \mathrm{vol}$ Solvent: $5 \%$ TBP in Amsco, 2 vol

Stages: 6 extraction, 5 scrub

The uranium loss to the aqueous stream was less than $0.01 \%$. High uranium decontamination was obtained by complexing nearly all the TBP with uranium. These decontamination factors are as large as those obtained when $\mathrm{Al}\left(\mathrm{NO}_{3}\right)_{3}$ is used as the salting agent in the Interim-23 flowsheet.

In a third variation of the acid Thorex flowsheet, Decalin was used as the diluent instead of Amsco to evaluate a flowsheet in which an acidic (4 $\mathrm{M} \mathrm{HNO}_{3}$ ) rather than an acid deficient feed was used (4). Amsco as a diluent for acidic thorium systems is probably impractical because of the low stability of $\mathrm{Th}\left(\mathrm{NO}_{3}\right)_{4} \cdot 2 \mathrm{TBP}$ in Amsco in the 
Table 3. Flooding Capacity and HETS for Pulsed Column Operating on Acid Thorex Flowsheet

Pulse amplitude: 1 in.

\begin{tabular}{|c|c|c|c|c|c|}
\hline \multirow[b]{2}{*}{ Column } & \multirow{2}{*}{$\begin{array}{c}\text { Pulse } \\
\text { Frequency, } \\
\text { cpm }\end{array}$} & \multicolumn{2}{|c|}{$\begin{array}{c}\text { Flooding Capacity, Total Flow, } \\
\text { gal } \mathrm{ft}^{-2} \mathrm{hr}^{-1}\end{array}$} & \multicolumn{2}{|c|}{ HETS, ft } \\
\hline & & $\begin{array}{c}\text { Top } \\
\text { Interface }\end{array}$ & $\begin{array}{c}\text { Bottom } \\
\text { Interface }\end{array}$ & $\begin{array}{c}\text { Top } \\
\text { Interface }\end{array}$ & $\begin{array}{l}\text { Bottom } \\
\text { Interfoce }\end{array}$ \\
\hline \multicolumn{6}{|c|}{ Sieve plate, 0.125 -in.-dia holes, $23 \%$ free area } \\
\hline Extraction & 50 & 1030 & 1690 & Th 2.1 & 4.0 \\
\hline Partitioning & $\begin{array}{l}30 \\
50\end{array}$ & $\begin{array}{l}950 \\
750\end{array}$ & & & \\
\hline Stripping & 35 & 1290 & 1290 & $\begin{array}{c}\text { Th } 6.1 \\
\text { U } 4.2\end{array}$ & 6.1 \\
\hline
\end{tabular}

Nozzle plate, 0.125 -in.-dia holes, $23 \%$ free area

\begin{tabular}{lrrr}
\hline Extraction & 30 & 1400 & \\
& 50 & 1250 & Th 2.5 \\
& 70 & 500 & \\
\hline
\end{tabular}

Nozzle plate, 0.188 -in.-dia holes, $23 \%$ free area

\begin{tabular}{|c|c|c|c|c|c|}
\hline Extraction & 50 & 2080 & 2280 & Th 6.1 & $\begin{array}{r}\text { Th } 4.0 \\
6.2\end{array}$ \\
\hline Stripping & 35 & & & $\cup 4.4$ & 5.0 \\
\hline
\end{tabular}

presence of nitric acid, which causes third phase formation. Since the solubility of the thorium-TBP complex is higher in Decalin than in Amsco, higher solvent saturation and hence higher decontamination would be expected $(31,32)$. In laboratory tests on the flowsheet

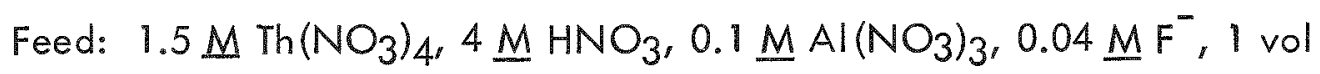
Scrub: $3.2 \mathrm{M} \mathrm{HNO} 3,0.003 \mathrm{M} \mathrm{H}_{3} \mathrm{PO}_{4}, 0.01 \mathrm{M} \mathrm{Fe}\left(\mathrm{NH}_{2} \mathrm{SO}_{3}\right)_{2}, 1$ vol 
Extractant: $42.5 \%$ TBP in Decalin, 5 vol

Stages: 5 extraction, 6 scrub

decontamination factors from ruthenium, zirconium-niobium, and rare earths were 90,300 , and $6.3 \times 104$, respectively, and the thorium loss to the aqueous was $0.07 \%$. These decontamination factors are at least a factor of 10 less than those obtained with the acid deficient feed for the acid Thorex process. An additional disadvantage is that the use of Decalin results in higher stage heights in a pulsed column, i.e., about $8.0 \mathrm{ft}$.

\subsection{Process Chemistry of Protactinium}

The control of protactinium remains as an unsolved problem in processing fuels containing macro ( $\sim 0.2 \mathrm{~g} /$ liter) concentrations of protactinium. In processing of 30day-decayed fuel in the Thorex pilot plant $(0.09-0.18 \mathrm{~g} /$ liter $\mathrm{Pa})$, the material balance was poor between the dissolver solution (5-7 $\mathrm{M} \mathrm{HNO} 3$ aged a few hours) and the adjusted feed (0.2-0.3 $\mathrm{M}$ acid deficient, aged several days) (12). Solids containing protactinium accumulated at the extraction column interface and adsorbed on vessel walls. Duplicate samples varied by $50 \%$ in protactinium content and the final raffinate, after decaying $1 \mathrm{yr}$, contained only $50 \%$ of the amount of U-233 predicted by protactinium analyses. The retention of protactinium in the extraction column at the interface and by adsorption on metal walls, or possibly by reflux, constitutes a serious operating problem because of $(a)$ entrainment of colloidal protactinium in the organic extract; (b) excessive solvent radiation degradation which in turn promotes emulsion formation by the surface-active metal-organo degradation products and low fission product decontamination factors; and (c) once hydrolyzed and polymerized, protactinium cannot be reconverted to a single state except by dissolution in concentrated acidic fluoride solution or a precipitation redissolution cycle. The anomolous behavior of protactinium in the runs with short-decayed fuel is attributed to the high concentration of protactinium and the resulting hydrolytic polymeric character of $\mathrm{Pa}(\mathrm{V})$ at low acidities in nitrate solutions in the absence of a large excess of fluoride.

Two alternatives for processing short-decayed fuel are being considered: (a) carrier-precipitation of protactinium in a head end step; (b) separation of thorium and uranium from protactinium by solvent extraction. After decay of protactinium to $\mathrm{U}-233$, the latter would be recovered in a separate operation, or (c) co-extraction of protactinium, uranium, and thorium in a low decontamination process. Precipitates such as zirconyl phosphate, thorium iodate, or thorium hydroxide have carried $99 \%$ of the protactinium from nitrate solutions in laboratory-scale tracer experiments, but the degree of hydrolysis of protactinium was uncertain (32). Similarly, in tracerscale experiments with protactinium in nitrate solutions, uranium and thorium have been extracted from protactinium with tributyl phosphate (45) and protactinium has been extracted from uranium and thorium with diisobutyl carbinol (46), but these systems have not been investigated with macro concentrations of protactinium. If a method for processing short-decayed fuel is to succeed, a positive means of re- 
taining protactinium in the ionic form prior to the separation step must be developed. Present knowledge indicates that the fluorides are the most stable protactinium complexes and that they are stable in concentrated $\mathrm{HCl}$ solution, but limited work has been done in the nitrate system where protactinium is unstable even at high acidities and with excess fluoride (43). The small amount of fluoride, $0.04 \mathrm{M}$, present in the Thorex process is complexed by the aluminum and chromium and prevents hydrolysis at tracer concentrations but is ineffective at $10^{-3} \mathrm{M}$ protactinium. Studies (44) in nitrate solutions, containing $10^{-7}$ to $10^{-4} \mathrm{M}$ protactinium and 0.5 to $10 \mathrm{M} \mathrm{HNO}_{3}$, over 24-hr periods showed reasonable stability, but nonreproducible hydrolytic precipitation was observed with $>10^{-4} \underline{M}$ protactinium and $<3 \underline{\mathrm{M}} \mathrm{HNO}_{3}$.

\subsection{New Solvents (8)}

Laboratory tests of several organophosphorous compounds of varied structure have indicated reagents that may have potential value in thorium recovery and separations processes (Table 4). Comparison of neutral phosphate and phosphonate strucfures with TBP showed that secondary branching of the alkyl groups, e.g. in TSBP or DSBPP, produces order-of-magnitude lower thorium extractability and higher U/Th separation factors. This characteristic was also observed generally in the case of U/ TRE and U/RU separation (Table 5). Higher U/Pa separation in the special case of TSBP (tri-sec-butyl phosphate) indicates that it may be effective in separations systems such as the Interim-23 process where only uranium is extracted and thorium remains with the fission products. It was also shown that phosphonate and phosphine oxides could not be used efficiently with Amsco-125-82 diluent (aliphatic) because of the limited solubility of the uranium and thorium complexes in this system.

Additional interest has been developed in the comparison of TBP with phenyl phosphonates, such as DBPP and DSBPP, because the unsaturated bonds of the phenyl group afford significantly radiolytic stability (37):

\begin{tabular}{|c|c|c|c|}
\hline \multirow{2}{*}{$\begin{array}{l}\text { Radiolysis } \\
\text { Product }\end{array}$} & \multicolumn{3}{|c|}{ G Values } \\
\hline & TBP & DBPP & $\overline{\text { DSBPP }}$ \\
\hline mono-acid & 2.07 & 0.78 & 0.54 \\
\hline gas & 1.87 & 0.49 & 0.33 \\
\hline
\end{tabular}

DSBPP, because it is $\sim 4$ times as stable as TBP and also affords considerably higher uranium-thorium separation (Table 4), is of specific interest as a possible TBP substitute in highly radioactive processes. Laboratory countercurrent tests showed that DSBPP may be a valuable reagent for the final purification of Thorex U-233 products from contaminants such as Th-232 or Th-228. 
Table 4. Extraction of Uranium and Thorium by Organophosphorous Reagents

(Listed in order of thorium extractability)

\begin{tabular}{|c|c|c|c|c|}
\hline Extractant & Diluent & $E_{a U}^{\circ}$ & $E_{a T h}^{\circ}$ & $\begin{array}{l}\text { Separation } \\
\text { Factor** }\end{array}$ \\
\hline $0.3 \underline{M}$ di (2-ethylhexyl)phosphoric acid (D2EHPA)* & Amsco $125-82$ & 13 & 1370 & 105 \\
\hline $1 \underline{M}$ di $($ n-butyl)n-butyl phosphonate & Amsco 125-82 & 540 & 43 & 13 \\
\hline I $\underline{M}$ di (n-butyl)phenylphosphonate (DBPP) & Xylene & 115 & 6 & 19 \\
\hline I $M$ tri (n-butyl)phosphate (TBP) & Amsco $125-82$ & 36 & 3.4 & 12 \\
\hline I $\underline{M}$ tri (iso-butyl)phosphate & Amsco $125-82$ & 37 & 1.9 & 20 \\
\hline I $\underline{M}$ tri (sec-butyl)phosphate (TSBP) & Amsco 125-82 & 63 & 0.26 & 240 \\
\hline I $\underline{M}$ di (sec-butyl)phenylphosphonate (DSBPP) & Xylene & 60 & 0.17 & 370 \\
\hline $0.1 \mathrm{M}$ tri (octyl)phosphine oxide & Amsco 125-82 & 3 & 0.15 & 21 \\
\hline
\end{tabular}

${ }^{*}$ Aqueous phase $0.5 \underline{\mathrm{M} \mathrm{Al}}\left(\mathrm{NO}_{3}\right)_{3}-0.5 \underline{\mathrm{M} \mathrm{HNO}} 3-0.04 \underline{\mathrm{MU}} \mathrm{U}, 0.06 \underline{\mathrm{M}} \mathrm{Th}$; other aqueous phases $4 \underline{\mathrm{M}} \mathrm{HNO}_{3}-$ $0.002 \underline{M} U-0.002 \underline{M}$ Th.

** Ratio of EU and ETh extraction coefficients.

Table 5. Extraction of Irradiated Fuel Constituents by $0.3 \mathrm{M}$ Organophosphorous Reagents Aqueous: $0.5 \underline{\mathrm{M} \mathrm{Al}\left(\mathrm{NO}_{3}\right)_{3}-0.5 \mathrm{M} \mathrm{HNO}}-0.04 \mathrm{M} \mathrm{U}-0.06 \mathrm{M} \mathrm{Th}$ O/A ratio: 1.0

\begin{tabular}{|c|c|c|c|c|c|c|c|c|c|}
\hline \multirow[b]{2}{*}{ Extractanft } & \multirow[b]{2}{*}{ Diluent } & \multicolumn{8}{|c|}{$\mathrm{E}_{\mathrm{g}}$} \\
\hline & & U & Th & $\operatorname{Pa} \gamma^{* *}$ & $\begin{array}{c}\mathrm{Zr}-\mathrm{Nb} \\
\gamma^{* *}\end{array}$ & $\operatorname{Ru} \gamma$ & TRE $\beta$ & $\begin{array}{l}\text { Gross } \\
\gamma^{* *}\end{array}$ & $\begin{array}{c}\text { Gross } \\
\beta\end{array}$ \\
\hline D2EHPA & Amsco 125-82 & 13 & 1370 & 4.5 & 4.9 & 0.015 & 0.005 & 1.8 & 0.08 \\
\hline TBP & Amsco 125-82 & 5 & 0.19 & 0.08 & 0.002 & 0.002 & 0.002 & 0.003 & 0.003 \\
\hline DBPP & Xylene & 11 & 0.18 & 0.03 & 0.003 & 0.001 & 0.001 & 0.003 & 0.002 \\
\hline$T(2 E B) P$ & Amsco 125-82 & 6 & 0.07 & 0.12 & 0.03 & 0.002 & 0.0006 & 0.024 & 0.006 \\
\hline TSBP & Amsco 125-82 & 12 & 0.04 & 0.03 & 0.004 & 0.0007 & 0.0003 & 0.004 & 0.001 \\
\hline TCP & Amsco 125-82 & 17 & 0.03 & 0.24 & 0.007 & 0.0008 & 0.0002 & 0.01 & 0.004 \\
\hline
\end{tabular}

${ }^{*} T(2 E B) P=\operatorname{tri}(2-e t h y l b u t y l)$ phosphate; $T C P=$ tricapryl phosphate.

* Extraction considerably increased by presence of even small concentrations of acidic impurities or hydrolysis products of the neutral reagents. 
Other information on radiolysis of diluted phenylphosphonate and TBP solvents indicates that the use of highly aromatic diluents affords higher stability of the alkyphosphates such as TBP (Table 6). The use of aromatic diluents also affords somewhat higher U/Th and U/FP separations (Table 7). Though the DSBPP-aromatic diluent system appears to offer advantages in both stability and separative powers as compared to the TBP-Amsco (aliphatic) system, the use of aromatic diluents with TBP effectively narrows the differences.

Table 6. Radiolytic Formation of Acids in Diluted TBP, DBPP, and DSBPP

\begin{tabular}{lll}
\hline Solvent & \multicolumn{2}{c}{$\begin{array}{c}\text { Acid in Solvent After } \\
\text { Co-60 Irradiation, N }\end{array}$} \\
\cline { 2 - 3 } 1 M whr/liter & 270 whr/liter \\
\hline TBP (Amsco 125-82*) & 0.0082 & 0.070 \\
1 M DBPP (Solvesso-100**) & 0.0057 & 0.026 \\
1 TBP (Solvesso-100**) & 0.0030 & 0.029 \\
\hline
\end{tabular}

*Mostly aliphatic diluent.

**Highly aromatic diluent.

Table 7. Extraction of $U$, Th, and Fission Products by $1 M$ TBP and $1 M$ DSBPP

Aqueous feed: $2.4 \mathrm{M} \mathrm{HNO}_{3}, 0.06 \underline{\mathrm{MU}}, 0.02 \mathrm{M} \mathrm{Th}$

\begin{tabular}{|c|c|c|c|c|c|c|c|}
\hline \multirow[b]{2}{*}{ Extractant } & \multicolumn{6}{|c|}{$E_{a}^{O}$} & \multirow[b]{2}{*}{ Gross $\beta$} \\
\hline & $\mathrm{U}$ & Th & $R u \gamma$ & $\mathrm{Zr}-\mathrm{Nb} \gamma$ & TRE $\beta$ & Gross $\gamma$ & \\
\hline TBP-Amsco 125-82 & 21.0 & 1.75 & 0.043 & 0.035 & 0.018 & 0.018 & 0.013 \\
\hline TBP-Xylene & 31.5 & 1.43 & 0.04 & 0.031 & 0.022 & 0.01 & 0.007 \\
\hline DSBPP-Xylene & 37.8 & 0.16 & 0.027 & 0.032 & 0.045 & 0.007 & 0.006 \\
\hline
\end{tabular}




\subsection{CORROSION $(\underline{33}, \underline{34)}$}

Titanium has been selected as the material of construction for the DarexThorex dissolver. Titanium corrosion rates are $\sim 1$ and $\sim 0.1 \mathrm{mil} / \mathrm{mo}$ in $5 \mathrm{M} \mathrm{HNO} 3-$ $2 \mathrm{M} \mathrm{HCl}$ and in $50 \mathrm{~g} /$ liter SS, $1.8 \mathrm{M} \mathrm{Cl}^{-}, 4.6 \mathrm{M} \mathrm{NO}_{3}^{-}, 3.9 \mathrm{M} \mathrm{H}^{+}$, initial and final decladding solutions, respectively. Corrosion rates are 1.6 and $1.5 \mathrm{mils} / \mathrm{mo}$ in $13 \mathrm{M} \mathrm{HNO}_{3}-0.04 \mathrm{M} \mathrm{F}^{-}-0.04 \mathrm{M} \mathrm{Al}^{3+}$ and in $1.0 \mathrm{M} \mathrm{Th}{ }^{4+}-8.5 \mathrm{M} \mathrm{HNO}_{3}-0.04 \mathrm{M}$ $\mathrm{F}=0.04 \mathrm{M} \mathrm{Al}\left(\mathrm{NO}_{3}\right)_{3}$, the beginning and final dissolver solutions, respectively. In 25 cyclic tests of decladding and dissolution, the overall average rate was $0.2 \mathrm{mil} /$ mo.

A low-carbon nickel alloy (LCNA, $0.005 \% \mathrm{C}$ ), closely approximating the composition of $\mathrm{Ni}-0-n e l(0.05 \% \mathrm{C}$ max) was selected as the metal of construction for the Sulfex-Thorex dissolver. Typical corrosion rates of LCNA in 4 and $6 \mathrm{M} \mathrm{H}_{2} \mathrm{SO}_{4}$ were 5.3 and $11.5 \mathrm{mils} / \mathrm{mo}$; in the presence of $35 \mathrm{~g}$ of dissolved stainless steel per liter the rates decreased to 1.2 and $1.6 \mathrm{mils} / \mathrm{mo}$, respectively. Corrosion rates were $\sim 4$ and $\sim 0.6 \mathrm{mil} / \mathrm{mo}$ in $13 \mathrm{M} \mathrm{HNO}_{3}-0.04 \mathrm{M} \mathrm{F}^{-}-0.1 \mathrm{M} \mathrm{Al} 3+$ and $1.0 \mathrm{M} \mathrm{Th} 4+-8.5 \mathrm{M}$ $\mathrm{HNO}_{3}-0.04 \mathrm{~F}^{-}-0.1 \mathrm{M} \mathrm{Al} 3+$, the beginning and final dissolver solutions, respectively. A laboratory dissolver used for 25 Sulfex decladding dissolution cycles showed an overall corrosion rate of $2.9 \mathrm{mils} / \mathrm{mo}$, but localized attack around welds was considerably more severe.

The best Ni-o-nel heat treatment prior to welding, in order to minimize corrosion in Thorex dissolver solution, is at $1800^{\circ} \mathrm{F}$. Test samples heated to temperatures between 1500 and $1800^{\circ} \mathrm{F}$ showed signs of localized corrosion in the heat-affected zone. Welds annealed for $1-2 \mathrm{hr}$ at 1850 to $1950^{\circ} \mathrm{F}$ and quenched showed the least corrosion.

\subsection{ENGINEERING CONCEPT}

Engineering studies (35) on criticality have included both evaluation of methods to prevent inadvertent criticality and an appraisal of the seriousness of accidents that would result from an accidental excursion. The dissolvers for the Darex and Sulfex-Thorex systems should probably be geometrically or near geometrically safe; in the latter case the addition of soluble neutron poisons to the dissolvents will be required. Batch control is probably not feasible because of the severe limits which it imposes on capacity. Equipment downstream from the dissolver will generally not be geometrically safe and will depend on concentration control or the use of soluble poisons or fixed poisons such as boron-glass packing to prevent criticality incidents. The soluble compounds of the neutron poisons boron, cadmium, and rare earths were found chemically compatible with the dissolution and extraction systems (Sects. 2.5, 3.1, and 3.2) (27, 29). The use of fixed poisons, specifically, boron-glass Raschig rings, has been studied and found practical from both the nuclear and process standpoint (36). In criticality tests with a $25 \%$ packed volume of glass rings containing $6 \%$ boron, U-235, U-233, 
and Pu-239, concentrations of $50 \mathrm{~g} /$ /iter in infinite geometry were proved safe. Calculations have shown that in such a system criticality cannot be reached at any concentration of practical interest; experimental verification of this fact is in progress.

Minimum dissolution time can be achieved in a tube dissolver (used in order to limit geometry for nuclear safety) by circulating dissolvent from a large dissolvent vessel to the dissolver and back. As the rate of circulation increases, dissolution approaches that which would be obtained in a large batch dissolver (Fig. 9). Because relatively small particles of fissile material might be carried out of the limited-geometry dissolver to the relatively unlimited-geometry dissolvent tank, means must be provided to collect such solids. The simplest means available is a geometrically safe settler which should be adequate. If not, a centrifuge could be used. Solids will accumulate as a residue in the dissolver and in the solids separation equipment. The detection of undissolved fissile oxides in these solids prior to discharge to waste presents a difficult problem for which no entirely satisfactory solution has been devised.

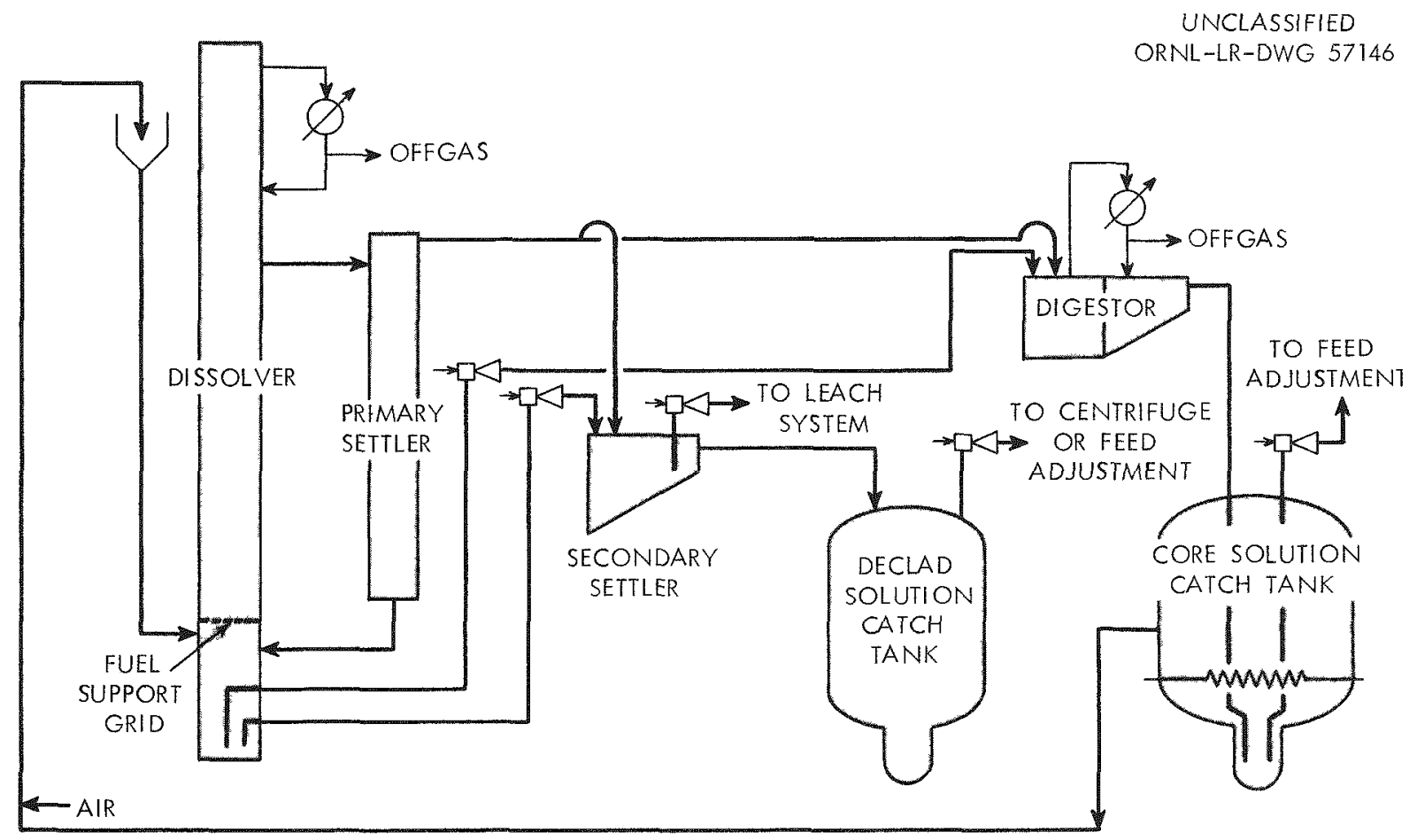

Fig. 9. Schematic of geometrically safe dissolution system. 


\subsection{REFERENCES}

1. L. M. Ferris and A. H. Kibbey, "Sulfex-Thorex and Darex-Thorex Processes for the Dissolution of Consolidated Edison Power Reactor Fuel: Laboratory Development," ORNL-2934 (Oct. 26, 1960).

2. L. M. Ferris, "Decladding of Consolidated Edison Power Reactor Fuel by Sulfex and Darex Processes: Cyclic Dissolution Experiments," ORNL-2822 (Jan. 13, 1960).

3. L. M. Ferris and A. H. Kibbey, "Laboratory Development of the Sulfex Process for the Dissolution of Consolidated Edison Power Reactor Fuel, "ORNL-2714 (Oct. 16, 1959).

4. R. E. Blanco, L. M. Ferris, J. R. Flanary, F. G. Kitts, R. H. Rainey, and J. T. Roberts, "Chemical Processing of Power and Research Reactor Fuels at Oak Ridge National Laboratory," in Proc. AEC Symposium for Chemical Processing of Irradiated Fuels from Power, Test, and Research Reactors, Richland, Wash., Oct. 20-21, 1959, TID-7583, p. 234.

5. "Chemical Technology Division Annual Progress Report for Period Ending Aug. 31, 1960," ORNL-2993.

6. B. C. Finney and B. A. Hannaford, "Sulfex Process: Engineering-scale Semicontinuous Decladding of Unirradiated Stainless Steel-clad $\mathrm{UO}_{2}$ and $\mathrm{UO}_{2}^{-}$ $\mathrm{ThO}_{2}$," ORNL-3072 (Mar. 22, 1961).

7. R. H. Rainey and J. G. Moore, "Laboratory Development of the Acid-Thorex Process for Recovery of Thorium Reactor Fuel, "Nucl. Sci. Eng., 10:367-371 (1961).

8. (a) C. A. Blake, Jr., A. T. Gresky, J. M. Schmitt, and R. G. Mansfield (ORNL), "Uranium and Thorium Separation with Di-sec-butyl phenylphosphonate and Ohter Reagents," ANS Annual Meeting, June 1960; (b) A. T. Gresky and R. G. Mansfield, "Comparisons of Organic Extracts for Irradiated Uranium: Tri-butyl phosphate vs Di-sec-butyl Phenylphosphonate, Di-n-butyl Phenylphosphonate, Tri-caprylphosphate, and Tri-sec-butyl phosphate," ORNL-CF 59-6-15, June 1959; (c) A. T. Gresky and R. G. Mansfield, "Uranium-Thorium Separation by Di-sec-butyl Phenylphosphonate Extraction," ORNL-CF 59-11-25; (d) A. T. Gresky and R. G. Mansfield, "UraniumPlutonium Separation and Decontamination," ORNL-2993, pp. 150-152, Chemical Technology Division Annual Progress Report for Period Ending August 31, 1960.

9. E. M. Shank, "Operation of the Thorium Pilot Plant with Highly Irradiated Thorium," Prog. in Nucl. Energy, Series III, Proc. Chem., Vol. 2, p. 279, Pergamon Press, London, 1958. 
10. F. R. Bruce, E. M. Shank, R. E. Brooksbank, J. R. Parrott, and G. S. Sadowski, "Operating Experience with Two Radiochemical Processing Pilot Plants," Proc. 2nd UN Internat'1. Conf. Peaceful Uses Atomic Energy, Geneva, 1958, Vol 17, P/536, p. 49, UN, New York.

11. F. L. Culler and R. E. Blanco, "Dissolution and Feed Preparation for Aqueous Radiochemical Separation Processes, "ibid., P/930, p. 259.

12. W. T. McDuffee, "Thorex Pilot Plant: Run AWD-2 Summary," ORNL-CF 60-3-4 (March 1960).

13. M. E. Brennan et al., "Fuel Recovery Process for the SIR Mark A, "KAPL-933 (July 17, 1953).

14. T. A. Gens, "Sulfex Process: Depassivation of Stainless Steel," ORNL-2785 (Nov. 6, 1959).

15. R. A. Ewing, H. B. Brugger, and D. N. Sunderman, "Dissolution of Irradiated Consolidated Edison Power Reactor Fuel by the Sulfex and Darex Processes," BMI-1427 (Mar. 10, 1960).

16. "Chemical Technology Division Annual Progress Report for Period Ending May 31, 1961," ORNL-3153.

17. D. E. Horner and C. F. Coleman, "Recovery of Uranium and Plutonium from Sulfuric Acid Decladding Solutions," ORNL-2830 (Nov. 11, 1959).

18. C. Orr, Jr., M. C. Kordecki, and C. T. Young, "A Study of Equilibria Involved between Darex Off-gases and Solutions, "ORNL Subcontract No. 1373 with Georgia Institute of Technology, Final Technical Report, TID-6501 (July 31, 1960).

19. K. S. Warren, "Survey of Potential Vapor-phase Explosions in Darex and Sulfex Processes," ORNL-2937 (Dec. 27, 1960).

20. T. A. Gens, "Measurement of Hazardous Components of Darex Process Off-gas," ORNL-3022 (April 17, 1961).

21. R. E. Blanco, "Preparation of Power Reactor Fuels for Processing by Solvent Extraction," Prog. in Nucl. Energy, Series III, Proc. Chem., Vol. 2, p. 223, Pergamon Press, London, 1958.

22. R. H. Rainey, ORNL, unpublished data, May 1961.

23. L. M. Ferris, "Process for Dissolution of BORAX-IV Reactor Fuel: Laboratory Development," ORNL-2821 (Jan. 18, 1960). 
24. L. M. Ferris, "Zirflex Process for PWR Blanket Fuel. II. Revised Flowsheet," ORNL-2940 (Oct. 26, 1960).

25. J. L. Swanson, "The Selective Dissolution of Zirconium or Zircaloy Cladding by the Zirflex Process," Proc. 2nd UN Internat'l. Conf. Peaceful Uses Atomic Energy, Geneva, 1958, Vol. 17, p. 154, UN, New York.

26. W. D. Bond, "Dissolution of Sintered Thorium-Uranium Oxide Fuel in Nitric Acid--Fluoride Solutions," ORNL-2519 (Oct. 28, 1958).

27. L. M. Ferris and A. H. Kibbey, "Miscellaneous Experiments Relating to the Processing of CETR Fuel by the Sulfex-Thorex and Darex-Thorex Processes," ORNL-3143 (Aug. 16, 1961).

28. A. B. Meservey and R. H. Rainey, "Process for Decontaminating Thorium and Uranium with Respect to Ruthenium," U. S. Patent 2,909,406 (Oct. 20, 1959).

29. J. G. Moore and R. H. Rainey, "Chemical Feasibility of Nuclear Poisons in Uranium-Thorium Fuel Processing Systems," Nucl. Sci. Eng., 11:278-284 (1961).

30. A. D. Ryon, "McCabe-Thiele Graphical Solution of Uranium-Thorium Partitioning from 30\% TBP-Amsco Solvent," ORNL-508 (March 1958).

31. W. W. Morgan, "The Processing of Irradiated Thorium Fuels Using Tributyl Phosphate-Decalin," AECL-508 (March 1958).

32. R. H. Rainey, A. B. Meservey, and R. G. Mansfield, "Laboratory Development of the Thorex Process: Progress Report Dec. 1, 1955, to Jan. 1, 1958, "ORNL2591.

33. P. D. Miller, C. L. Peterson, et al., "Evaluation of Container Materials for Zircex and Darex Nuclear Fuel Recovery Processes," BMI-1242 (Dec. 11, 1957).

34. C. L. Peterson, "Construction Materials for Various Head-end Processes for the Aqueous Reprocessing of Spent Fuel Elements," BMI-1375 (Aug. 28, 1959).

35. A. R. Irvine et al., "A Review of Factors Bearing on the Nuclear Safety of Equipment for the PRFR Headend Facility," ORNL-CF 60-1-102, January 1960.

36. J. P. Nichols, "Hazards Evaluation of Proposed Glass-packed U-233 Storage System," ORNL-CF 61-2-54 (Feb. 20, 1961).

37. R. M. Wagner and R. Farrand, "Radiation Stability of Organic Liquids," ORNL Subcontract 1081, Stanford Research Institute, Semiannual No. 6 for Period Ending December 1, 1959, SRI Project No. SD-2080. 
38. L. M. Ferris, ORNL, unpublished data, May 1961.

39. M. J. Bradley and L. M. Ferris, "Recovery of Uranium and Thorium from Graphite Fuel Elements. I. Grind-Leach Process," Nucl. Sci. Eng., 8:432 (1960).

40. M. J. Bradley and L. M. Ferris, "Recovering Uranium from Graphite Fuel Elements," Ind. Eng. Chem., 53:279 (1961).

41. K. S. Warren, L. M. Ferris, and A. H. Kibbey, "Dissolution of BeO- and $\mathrm{Al}_{2} \mathrm{O}_{3}$ Base Reactor Fuel Elements," ORNL-3220 (in press).

42. G. I. Cathers, ORNL, unpublished data, June 1, 1961.

43. H. W. Kirby, "The Radiochemistry of Protactinium," NAS-NS-3016, Nat. Acad. Sci. (1959).

44. C. J. Hardy, D. Scargill, and J. M. Fletcher, "Studies on Protactinium(V) in Nitric Acid Solutions," J. Inorg. Nucl. Chem., 7:257 (1958).

45. A. T. Gresky, "Separation of U-233 and Thorium from Fission Products by Solvent Extraction," Prog. in Nucl. Energy, Series III, Proc. Chem., Vol. I, Pergamon Press, London, 1956.

46. J. Oliver, J. R. Meriwether, and R. H. Rainey, "Extraction of Protactinium with Di-iso butylcarbinol," ORNL-2668 (April 2, 1959). 
ORNL-3219

UC-10-Chemical Separations Processes for Plutonium and Uranium TID-4500 (17th ed.)

\section{INTERNAL DISTRIBUTION}

1. Biology Library

2-3. Central Research Library

4. Reactor Division Library

5. ORNL - Y-12 Technical Library Document Reference Section

6-25. Laboratory Records Department

26. Laboratory Records, ORNL R.C.

27. E. D. Annold

28. C. Blake

29. R. E. Blanco

30. G. E. Boyd

31. J. C. Bresee

32. K. B. Brown

33. F. R. Bruce

34-35. F. L. Culler

36. D. E. Ferguson

37. L. M. Ferris

38. J. H. Frye, Jr.

39. J. H. Gillette

40. H. E. Goeller

41. A. T. Gresky

42. W. R. Grimes

43. C. E. Guthrie

44. C. W. Hancher

45. C. S. Harrill

46. A. Hollaender
47. A. S. Householder

48. R. G. Jordan $(Y-12)$

49. W. H. Jordan

50. M. T. Kelley

51. J. A. Lane

52. C. E. Larson

53. T. A. Lincoln

54. S. C. Lind

55. K. Z. Morgan

56. J. P. Murray $(K-25)$

57. D. Phillips

58. R. H. Rainey

59. H. E. Seagren

60. M. J. Skinner

61. J. A. Swartout

62. E. H. Taylor

63. J. W. Ullmann

64. W. E. Unger

65. A. M. Weinberg

66. M. E. Whatley

67. R. G. Wymer

68. J.W. Youngblood

69. D. L. Katz (consultant)

70. T. H. Pigford (consultant)

71. H. Worthington (consultant)

\section{EXTERNAL DISTRIBUTION}

72. W. H. Reas, Hanford

73. S. Lawroski, Argonne National Laboratory

74. L. P. Hatch, Brookhaven National Laboratory

75. B. Manowitz, Brookhaven National Laboratory

76. J. J. McBride, Idaho Chemical Processing Plant

77. J. W. Morris, Du Pont, Savannah River

78. V. R. Thayer, Du Pont, Wilmington

79. Division of Research and Development, AEC, ORO

80-587. Given distribution as shown in TID-4500 (17th ed.) under Chemical Separations Processes for Plutonium and Uranium category (75 copies - OTS) 